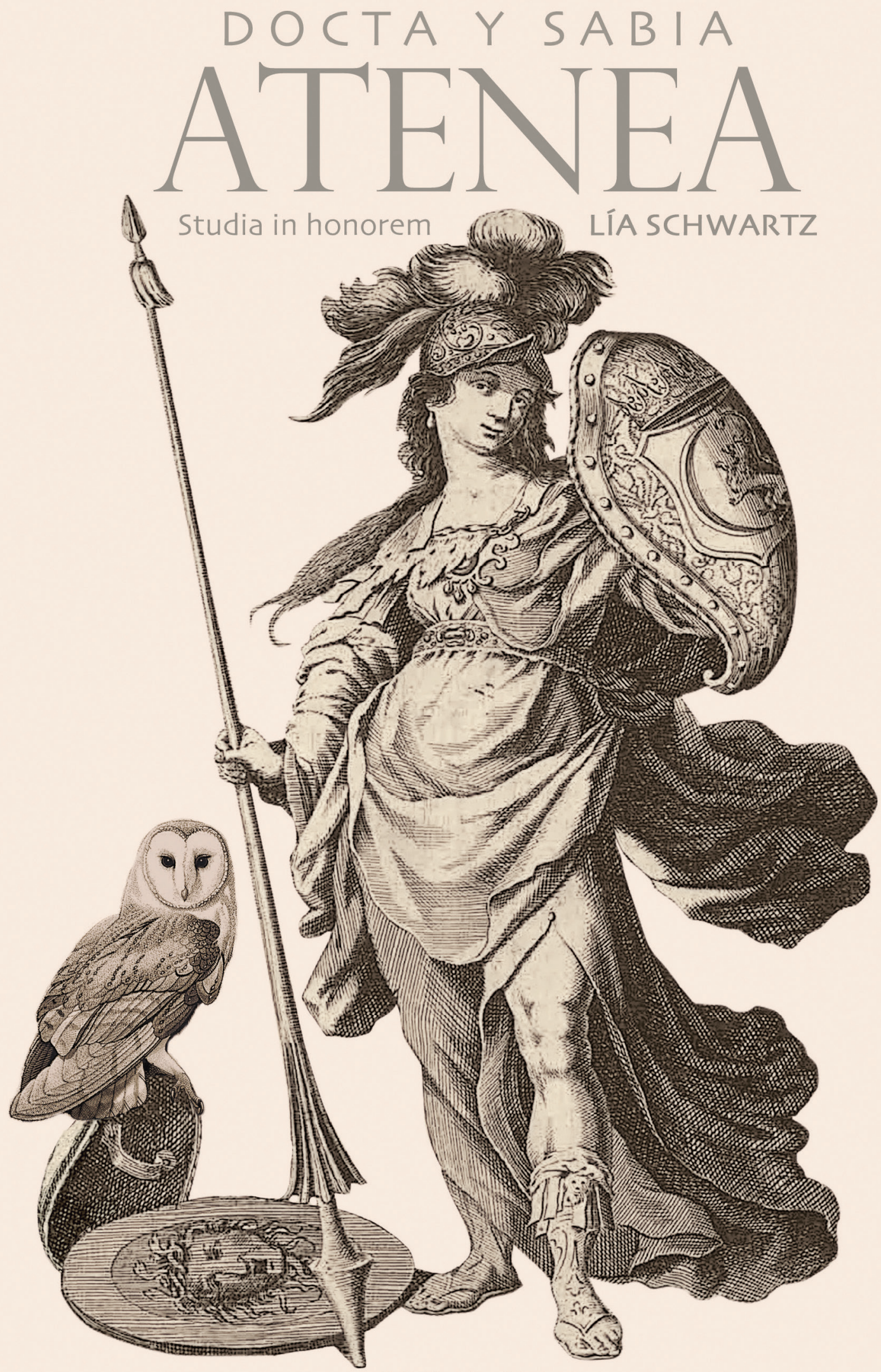

Edición al cuidado de:

SAGRARIO LÓPEZ POZA, NIEVES PENA SUEIRO, MARIANO DE LA CAMPA, ISABEL PÉREZ CUENCA, SUSAN BYRNE Y ALMUDENA VIDORRETA 



\section{DOCTA Y SABIA ATENEA Studia in honorem Lía Schwartz}

Edición al cuidado de:

Sagrario López Poza, Nieves Pena Sueiro, Mariano de la Campa, Isabel Pérez Cuenca, Susan Byrne y Almudena Vidorreta

A Coruña, 2019 

Profesora Lía Schwartz

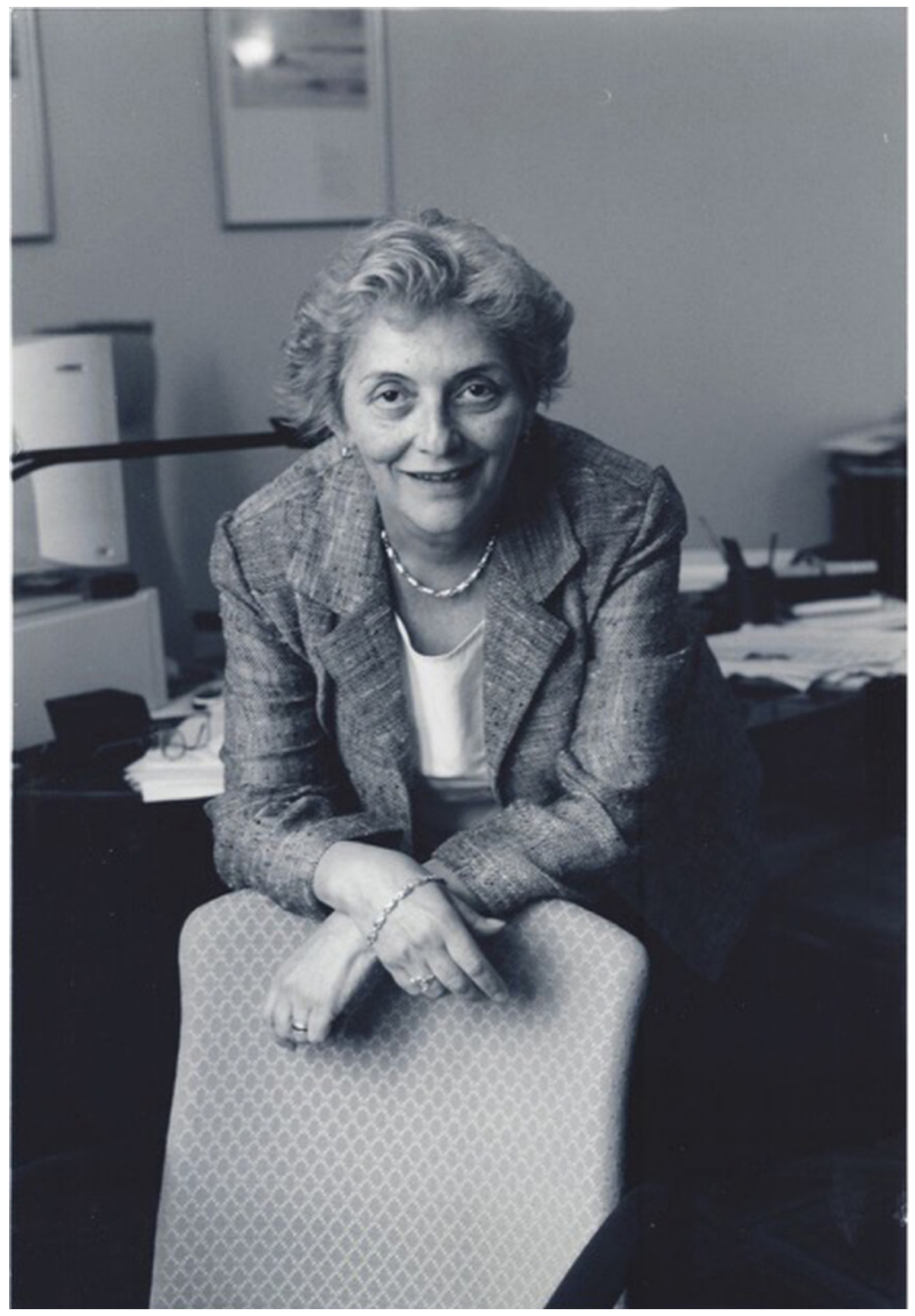


Sagrario López Poza, Nieves Pena Sueiro, Mariano de la Campa, Isabel Pérez Cuenca, Susan Byrne, Almudena Vidorreta (editores)

Docta y sabia Atenea. Studia in honorem Lia Schwartz

N. ${ }^{\circ}$ de páginas: 832

$17 \mathrm{x} 24 \mathrm{~cm}$.

Índice: pp. 7-10

ISBN: 9788497497046

Depósito Legal: C 53-2019

CDU: $821.134 .2(082.2) *$ SCHWARTZ

IBIC: DS | 2ADS | DQ

Editan:

Universidade da Coruña, Servizo de Publicacións

Instituto Universitario "La Corte en Europa" (IULCE), Universidad Autónoma de Madrid

Hispanic Seminary of Medieval Studies (HSMS), New York

Queen Sofía Spanish Institute, New York

Seminario Interdisciplinar para el estudio de la Literatura Áurea Española (SIELAE), Grupo Hispania, Universidade da Coruña

(C) Los autores

(C) De esta edición:

Servizo de Publicacións, Universidade da Coruña

Colección: Homenaxes n. ${ }^{\circ} 14$

Diseño de la cubierta: Paula Lupiáñez (Cirugía Gráfica. Madrid)

Interior: Juan de la Fuente

Impreso en Lugami Artes Gráficas, Betanzos (España)

Printed in Spain 


\section{ÍNDICE}

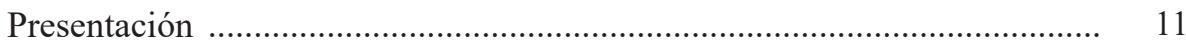

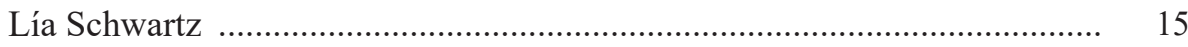

Bibliografía de Lía Schwartz ................................................................. 19

\section{Estudios en homenaje a la profesora Lía Schwartz}

Antonio Azaustre

Notas sobre la filiación en la tradición manuscrita de El alguacil endemoniado

Mercedes Blanco

Para una definición del gongorismo. El caso de Nueva España

69

JAVIER BLASCO

«Salta Pan, Venus baila, Bacho entona»: el campo léxico de la música como vehículo del erotismo en la poesía de los Siglos de Oro

SUSAN BYRNE

La armonía neoplatónica en "A Francisco de Salinas» de fray Luis de León

Mariano de La CAMPa

Poemas de Quevedo en impresos del siglo XVII: Los Romances varios .....

Manuel Ángel Candelas

La poesía española en los manuscritos de la Biblioteca Nazionale di Napoli: noticias y textos

ANTONIO CARREÑo

Lope de Vega: «Rompa ya el silencio el dolor en mí»

Donald CRUickshank

Don Toribio Cuadradillos, «avestruz del amor», and El lindo don Diego (with a note on Quevedo) 
María D'Agostino

Un juego de espejos deformantes. La «representación» del conde de Lemos entre Argensola y Cervantes

TREVOR J. DADSON

«Yo no puedo salir del trabajo de parecer a los portugueses castellano y a los castellanos portugués»: Diego de Silva y Mendoza y la poesía hispanoportuguesa de principios del siglo XVII

Ottavio Di Camillo

Of Roasted Eggs and Other Issues in the Celestina

Aurora EGIDO

Retórica y poética de los afectos en el soneto XIV de Garcilaso 265

Santiago Fernández Mosquera

El vicio de la virtud en Los trabajos de Persiles y Sigismunda 283

Flavia Gherardi \& Pedro Cátedra

El Discorso in difesa della poesia de Gian Ambrogio Biffi en el ámbito de la poética italiana y española

AdRIÁN M. IZqUiERDO

Paráfrasis y experimentación poética en el Anacreón castellano de Quevedo

HILAIRE KALLENDORF

Splitting Hairs or Finding Threads: The Labyrinth as Metaphor for Moral Dilemma in the Comedia

José ENRIQUE LAPLANA

La erudición en el Para todos de Juan Pérez de Montalbán

Begoña LóPEZ Bueno

El Ramillete de las Musas Castellanas (Bibliothèque Mazarine, ms. 4047): un canon literario español en el siglo XVII francés. Primera parte

SAGRARIo LóPez PozA

«Amoris vulnus idem sanat, qui fecit». Notas sobre la fortuna de un topos clásico

ISABEL LOZANO RENIEBLAS

El mal latín del episodio de dos falsos cautivos del Persiles 
Alison Maginn

Rubén Darío's Final Chapter: Archer Milton Huntington and the Hispanic Society

Miguel Martínez

Góngora asiático. Notas sobre poesía filipina inédita del primer Barroco ....

José Martínez MiLlán

Isabel Clara Eugenia, ¿una infanta castellana?

Clayton McCarl

Hacia un modelo para el marcado semántico de los textos marítimos de la época colonial

\section{Juan Montero Delgado}

Un soneto desconocido de Pedro Espinosa a Francisco de Rioja en el ms. Span 56 de la Houghton Library (Universidad de Harvard) 561

Nuria Morgado

Pervivencia del Barroco en la poética de la modernidad: intuiciones y conceptos en el pensamiento literario de Antonio Machado

FRANCISCA MOYA DEL BAÑo

La presencia de Plauto en Quevedo

VALENTINA NIDER

El oro como botín en los poemas de Quevedo sobre Belisario (B-267 e

B-281) y el contexto literario hispano-italiano

ISABEL PÉREZ CUENCA

Francisco de Quevedo y Antonio Sancho Dávila y Toledo Colonna, III marqués de Velada

FERnANDo Plata

El sentido de «barranco» en La Perinola de Quevedo y en otros textos del Siglo de Oro 653

José María Pozuelo Yvancos

Interdiscursividad: cine y literatura en Javier Cercas 671

Augustin Redondo

El tema de la mujer caída de una torre abajo: tradiciones culturales (grecolatinas, bíblicas, folklóricas), creencias religiosas y creaciones cervantinas ... 
MANUEl Rivero RODRÍGUEZ

El conde duque de Olivares, mecenas de la Historia y creador de opinión ... 701

MARIE RoIG Miranda

Los Sueños de Quevedo o cierto tipo de novela 723

Melchora Romanos

Séneca en las Anotaciones de Pedro Díaz de Rivas a los poemas mayores de Góngora

JAVIER SAN JosÉ LeRA

La Política de Dios de Quevedo como comentario bíblico: Política, Biblia y Literatura

LuIs SÁNCHEZ LAÍlLA

Ignacio de Luzán y la musa bucólica

Almudena Vidorreta

Teresa de Jesús, precursora de Gabriela Mistral y Alfonsina Storni

JUAN DiEgo VILA

«con las ansias de la muerte»: El aparato prologal del Persiles como programa estético del estilo tardío cervantino 


\title{
Isabel Clara Eugenia, ¿una infanta castellana?*
}

\author{
José MartíneZ MiLlÁN \\ IULCE - Universidad Autónoma de Madrid
}

A pesar de que el personaje ha sido objeto de numerosos y excelentes trabajos durante las últimas décadas, no creo que se haya logrado descifrar la compleja evolución política y personal de Isabel Clara Eugenia (reflejo de una época), a quien siempre presentan como hija fiel y obediente de su padre. A través de las noticias sueltas que espontáneamente he podido leer en los documentos de archivos cuando investigaba sobre Felipe II, se me fue configurando una imagen de la Infanta (sin que me detuviera a reflexionar sobre ello), cuya evolución vital me aparecía exactamente opuesta a la de su tía, la princesa doña Juana de Austria (1535-1573) ${ }^{1}$, a quien apenas conoció, si bien ambas tuvieron como gozne común al rey Felipe II. Doña Juana había nacido (1535) en medio de "libertad ideológica" en el que el humanismo y la espiritualidad reformista (ella misma había practicado la espiritualidad "recogida", íntima y vivencial, incluso ingresó en la Compañía de Jesús) aún dominaban Europa. El proceso confesional que se fue imponiendo en los distintos reinos europeos a mediados del siglo XVI, debido a la expansión de las ideas reformistas, llevó a la intransigencia religiosa y a la imposición de sistemas ideológicos cerrados sin posibilidad de crítica ni discrepancia. En la Monarquía hispana, tal cambio se puso de manifiesto para toda la sociedad en los autos de fe de 1559, en el tribunal de la Inquisición de Valladolid, en los que la

* Este trabajo se ha realizado en el marco del proyecto HAR2015-68946-C3-1-P, financiado por el Ministerio de Economía y Competitividad del Gobierno de desde el 01/01/2016 hasta el 31/12/2019.

1 Martínez Millán (1994, cap. 2º). 
propia princesa doña Juana, como regente "de estos reinos", tuvo que presidir. Ello le supuso, a nivel personal, la auto-represión ideológica y la adopción de una espiritualidad "racional" y formalista, que no compartía, al mismo tiempo que contemplaba con dolor la persecución a que eran sometidos sus amigos. Unos años después (1566), nacía la infanta Isabel Clara Eugenia en medio del ambiente intransigente que se había impuesto en la Monarquía, al mismo tiempo que un grupo de letrados castellanos organizaba institucionalmente la Monarquía hispana, basándose en la idea de "Monarquía Universal", adaptándola a un "catolicismo político castellano" y a su tradición sociocultural.

El sistema político-religioso impuesto por el Rey Prudente suscitó numerosas disensiones, tanto en el interior de la sociedad hispana como en los poderes políticos europeos. Si en las relaciones internacionales, las discrepancias dieron por resultado las numerosas guerras en las que se implicó el Rey Prudente a lo largo de su reinado, en el campo religioso se manifestó en el surgimiento de una espiritualidad radical, denominada movimiento "descalzo". De esta manera, sin pretenderlo, la espiritualidad "descalza" (discrepante de la religiosidad impuesta por Felipe II) fue asumida por las elites de los reinos, que habían sido excluidas del gobierno central de la Monarquía por los "letrados castellanos". Bajo el halo de hija fiel y obediente, con que se presenta a Isabel Clara Eugenia, la Infanta asimiló paulatinamente esta ideología religiosa discrepante a partir de las dos últimas décadas de la vida de su padre, manifestándose de manera clara durante su estancia en los Países Bajos. Tal comportamiento culminó en el período de regencia durante los años en que se encontró viuda (1621-1633). Durante esta etapa parece que actuó más como una católica dependiente directamente de los consejos de Roma que como gobernante de la Monarquía hispana.

Para demostrar estas afirmaciones y evitar moverme en el campo evanescente de las elucubraciones y opiniones, realizaré mi investigación a través de los servidores que tuvo Isabel a lo largo de su vida, la ideología que compartían y la religiosidad que practicaban. 


\section{Isabel Clara Eugenia, una infanta CaStellana}

La infanta Isabel Clara Eugenia, hija de Felipe II y de Isabel de Valois, nació el 12 de agosto de 1566 en Valsaín (Segovia) ${ }^{2}$. El agudo cronista Luis Cabrera de Córdoba, que distinguía muy bien los sucesos relevantes de la Monarquía de los que carecían de trascendencia, apenas concedía ocho líneas a dar la noticia de su nacimiento, que le servían para entrelazar dos acontecimientos distintos, pero - a su juicio - de mayor relevancia: la llegada del Turco a Italia y las primeras alteraciones que se producían en Flandes ${ }^{3}$. La princesa nacía en las mismas fechas en que su padre, Felipe II, comenzaba a configurar su monarquía (la Monarquía hispana), tanto administrativa como ideológicamente, ayudado por un grupo de letrados castellanos encabezados por Diego de Espinosa. Hacía una década en que había recibido en Bruselas (1555) la heterogénea herencia de reinos y territorios de manos de su padre, el emperador Carlos V, y decidió volver a Castilla para dar forma política a tan compleja herencia y evitar, al mismo tiempo, la expansión del luteranismo que había surgido en determinadas ciudades castellanas. Antes de regresar a los reinos peninsulares no se olvidó de concluir la paz con la Monarquía francesa y acabar el largo conflicto (que también había heredado de su padre) con la paz de CateauCambresis, sellándola con el compromiso de matrimonio con Isabel de Valois, hija del monarca francés Enrique $\mathrm{II}^{4}$. Una vez que llegó a la península en 1559, convocó Cortes a finales de este año, que se reunieron en Toledo en 1560. Las Cortes de Toledo constituyeron el inicio del reinado, que se caracterizó por la formación de la Monarquía hispana; en ellas se presentaron ante el Reino los miembros que componían la familia real, con sus casas y servidores, mientras que se proyectaron los principios políticos que las iban a regir y la ideología religiosa que se debía asumir.

\section{González Amezúa y Mayo (1949, II: 363-364).}

3 «Hallábase el Rey en el bosque de Segovia gozando de lo que en su palacio de Valsaín aumentó en edificio, fuentes y jardines, y pasando el estío regaladamente. A doce de agosto, fiesta de santa Clara, lunes a las dos horas después de media noche, parió la reina doña Isabel una hija. Para su baptismo hubo competencia entre don Diego de Covarrubias, en cuya jurisdicción y feligresía de su obispado está Valsaín, y el arzobispo de Santiago, cura de la Casa Real y capellán mayor sin exercicio, pretendiendo tocaba a cada uno. Para que cesase, pidió al nuncio de su Santidad, Juan Bautista Castaño, hiciese este oficio. Fueron padrinos el príncipe don Carlos y la princesa doña Juana, su tía, y le llamaron Clara por el día de su nacimiento; Isabel, por su madre; Eugenia, porque truxo el Santo» (Cabrera de Córdoba, 1998, I: 345).

4 Cabrera de Córdoba (1998, I: 187-189). 


\subsection{Los primeros sirvientes de Isabel Clara Eugenia}

Al poco de nacer en Valsaín, la infanta Isabel Clara Eugenia fue confiada a un grupo de servidores, que le iban a acompañar durante los primeros años de su vida:

[...] el mayordomo mayor, don Alonso de la Cueva, con el Aya, doña Elvira Carrillo, a quien se cuentan por gajes de su cargo dos mil ducados anuales. Pertenecía doña Elvira a una linajuda familia; fueron sus padres don Pedro Carrillo y doña Leonor Manrique, y ella había casado con don Bernardino de Mendoza, hermano del famoso poeta y diplomático don Diego. A las órdenes de doña Elvira y para cuidado de la tierna niña, figuran una criada, doña Leonor de Vibanco, y la indispensable dueña, doña Brianda de Villacorte, ..., con quince mil y veinte mil maravedíes de salario, respectivamente; una lavandera de corps, Juliana Rabín, y cinco criados más, para las restantes necesidades del servicio de la Infanta ${ }^{5}$.

Una rápida lectura señala que los personajes principales pertenecían al círculo "ebolista" (muchos de ellos habían estado en las Cortes de Toledo de 1560), y eran los mismos que habían servido en la casa de su madre Isabel de Valois y de su tía la princesa doña Juana.

El 3 de octubre de 1568 falleció Isabel de Valois, cuando la Infanta contaba dos años de edad y su hermana, Catalina Micaela, uno. Felipe II aprovechó esta desgracia para cambiar algunas mujeres que cuidaban de sus pequeñas hijas e, inmediatamente, ordenó al cardenal Espinosa (patrono del partido "castellano") que trasmitiera a la duquesa de Alba el mandato de que se hiciera cargo de tan importante cuidado ${ }^{6}$. De acuerdo con la orden, la marquesa de Frómista (doña Aldonza de Bazán) era nombrada camarera mayor de las infantas en 1570, pero al año siguiente, fue sustituida en el cargo por doña María Chacón (condesa de Berlanga), que ejerció de aya hasta 1576; en esta fecha, ocupó el cargo doña María Manrique, marquesa de Cenete. Ambas damas habían servido como dueñas de honor de la reina Isabel hasta su muerte.

Con la llegada a Madrid de la reina Ana, en 1570, cuarta esposa de Felipe II, Isabel y Catalina pasaron a ser servidas por los criados de la casa

5 «Casa de la Serenísima Infanta» (AGS. Casa Real, leg. 40), reproducido en González Amezúa y Mayo (1949: Apéndice II).

6 IVDJ, envío 82, caja 132, citado por Martínez Hernández (2009 : 24, nota 14). 
de la nueva reina ${ }^{7}$. La casa de la reina siempre se había construido sobre el modelo de la casa de Castilla, que había establecido Isabel la Católica y heredaron sus hijos, el príncipe Juan y la infanta Juana (después reina de Castilla), pero que no tenía Ordenanzas escritas, sino que se gobernaba por la costumbre, por lo que Felipe II quiso reformarla. Parecía que durante el período de la reina Isabel de Valois (el más largo) se iban a redactar unas Ordenanzas ${ }^{8}$, incluso, parece que hubo unos inicios de Ordenanzas de la casa, de acuerdo con la idea que Felipe II había proyectado, al mismo tiempo que buscaba reducir los excesivos gastos que ocasionaba la actividad de dicha reina, pero su muerte impidió que se interrumpieran los proyectos 9 .

Por eso, cuando Felipe II se decidió a contraer matrimonio con su sobrina Ana, antes de que llegara a Castilla, ya había ordenado que se elaborasen las ordenanzas de la casa de la futura reina ${ }^{10}$. Los deseos del monarca se cumplieron con rapidez porque, el 11 de enero 1570, el secretario Martín de Gaztelu comunicaba al rey que las ordenanzas estaban acabadas a falta de pequeños detalles ${ }^{11}$. No obstante, las duras pugnas de los partidos cortesanos por acaparar los cargos del servicio produjeron que se retrasara. Cuando Felipe II marchó a Córdoba (1570), con el fin de vigilar el final del levantamiento de los moriscos, encargó a Diego de Espinosa, al marqués del Adrada y a Martín de Gaztelu que se reunieran para acordar los servidores que debían ocupar los cargos de la nueva casa de la reina ${ }^{12}$. La tarea no resultó fácil, no sólo porque cada patrono quiso introducir a los miembros de su partido, sino también porque muchos de los servidores de la reina Isabel de Valois intentaron alcanzar el mismo cargo en la casa de la nueva reina ${ }^{13}$.

La muerte de la reina Ana, en 1580, dio mayor protagonismo a Isabel Clara Eugenia (ya tenía 14 años de edad) en la corte de Felipe II al constituirse en la principal referente femenina de la familia real. Desde luego, las principales casas nobiliarias se disputaban un cargo en el servicio de la infanta para sus hijas; asimismo, los poetas y hombres de letras hacían

7 González Amezúa y Mayo (1949: 367).

8 Rodríguez-Salgado (2003: 71-98).

9 AGS. CSR, leg. 41, exp. 1. Archivo Zabálburu, carpeta 152, doc. 18.

10 El tema lo estudié en Martínez Millán (2000 : 159-184)

11 AHN. Consejos, leg. 15.189, doc. 5

12 AHN. Consejos, leg. 15.188, doc. 1 y 26

13 Ibid. doc. 60 
referencia continua en sus comedias o en sus obras poéticas o musicales a la corte de la Infanta. Así se observa en la obra El Pastor de Fílida, en la que Luis Gálvez de Montalvo hace una relación de las damas que se hallaba ${ }^{14}$. Entre las más importantes se encontraban doña Ana Manrique, condesa de Puñoenrostro, dueña de honor; doña María Colonna; doña María de Aragón; doña Guiomar de Melo; doña María Manuel; doña Beatriz de Bolea; doña Luisa de Lasso; doña Magdalena de Borja; doña Francisca Manrique, dama; doña Juana Jacincourt (que había llegado a Castilla con la reina Isabel de Valois); doña Ana y doña Hipólita de Dietreichtein; doña Juana Manrique, dama; doña Isabel de Haro; doña Juana Henríquez, duquesa del Infantado y dueña de honor, y su hija doña Ana de Mendoza; doña Isabel de Aragón y Mendoza, marquesa de la Guardia; doña Catalina de de Zúñiga, condesa de Andrade; doña María Toledo; doña Brianda de Beaumont; doña Luisa Manrique de Lara, duquesa de Maqueda; doña Isabel de la Cueva, duquesa de Osuna, dama; doña Guiomar Pardo Tavera; doña Inés de Zúñiga; doña Luisa de Cárdena, condesa de Aguilar; doña Magdalena de Guzmán, marquesa del Valle; doña Inés Pacheco, condesa de Chinchón; doña Juana de la Cueva, duquesa de Medinaceli y doña Ana de la Lama, su hija; doña María Pimentel, condesa de Olivares; doña Ana Félix, condesa de Ricla; doña María de Peralta, doña Inés Chacón, doña María de Córdoba, marquesa de Estepa; doña Ana de Toledo Colonna, marquesa de Velada y su hija doña Antonia de Toledo; Catalina de Mendoza, marquesa de Mondéjar, etc. ${ }^{15}$.

Esta corte festiva compartía una ideología política y una manera de vivir la espiritualidad que divergía en muchos aspectos de la ortodoxia castellana tan querida por Felipe II. En 1581 se instalaba en el convento de las Descalzas Reales la emperatriz María, hermana de Felipe II, donde permaneció hasta su muerte, ocurrida en 1603. Las elites de los reinos, residentes en la corte y desplazadas de los organismos de gobierno, se vincularon entre sí reivindicando una composición de la Monarquía distinta de la proyectada por el grupo castellano, al mismo tiempo que buscaban la protección de los miembros de la familia real para influir en las decisiones que tomaba el monarca ${ }^{16}$; así se explica la conducta del círculo de aragoneses

14 Se ha hecho eco de esta relación, Martínez Hernández (2009: 34).

15 Gálvez de Montalvo (2006: 448-455). Olmedo Ramos (2009: 236-237) consigue presentar una relación bastante completa de servidoras a través de fuentes literarias de la época.

16 Intuyen este cambio y estudian con gran precisión la forma de vida de esta nueva espiritualidad: Sánchez Lora (1988). Lehfeldt (1999: 1009-1030). 
que se refugió en torno a la emperatriz María y el halo de "oposición” que siempre caracterizó a los personajes que frecuentaron el convento de las Descalzas o el grupo de "resignados" al viaje que integró el servicio de la infanta Catalina Micaela en su viaje a Saboya ${ }^{17}$. Todos ellos adoptaron, como forma de vida y práctica espiritual, la religiosidad dirigida directamente por el papado (relegado también en el campo político como ellos), formando así una ideología (política y religiosa) opuesta a la que venía ejerciendo el partido castellano ${ }^{18}$.

Dada la vinculación de la Monarquía con la confesión católica, Isabel Clara Eugenia estuvo educada en firmes convicciones religiosas y fue una persona muy devota ${ }^{19}$. Su compromiso religioso le llevó a favorecer la orden del Carmelo, especialmente el "descalzo", que después introdujo en Flandes ${ }^{20}$. Leyó y meditó los escritos de santa Teresa, aunque no la conoció personalmente; sin embargo, ambas mujeres llevaron una evolución muy semejante en su vida interior: si por una parte, se sometían a la religiosidad formalista (expresión de una espiritualidad "intelectual") impuesta por Felipe II y los letrados castellanos ${ }^{21}$, sus vivencias interiores denotaban una espiritualidad más radical y personal que rompían las estructuras establecidas. La Infanta conoció a Luisa de Carvajal, dado que "ésta se crio en la corte al cuidado de su tía abuela doña María Chacón, aya de Isabel y Catalina"22, cuya espiritualidad radical compartía.

\subsection{La casa de Isabel Clara Eugenia y del príncipe Felipe (1585-1598)}

Tras la muerte de la reina Ana (1580) y el matrimonio de su hermana Catalina Micaela (1585) comenzaron a manifestarse sus nuevas tendencias religiosas, discrepantes con el catolicismo confesional impuesto por su padre a toda la sociedad. Por eso, cuando se quedó sola en la corte, los

17 Sobre el círculo aragonés y la protección que ejerció doña María, Instituto Valencia de Don Juan (IVDJ), env. 101, fols. 128r, 138r, 139r. Howard Green (1945: 30-49). También, Martínez Millán (1999b: III, 143-163). Tormo (1917: 153-177) se hace eco de esta oposición de las Descalzas. La lista de servidores de Catalina Micaela que llevó a Saboya, en: AGS. Consejo Real, leg. 613, y la lista de los que volvieron a Castilla tras su muerte, en AGS. CJH, leg. 473, carp. 13.

18 Cruz Medina (2003: 523-534).

19 Whyhe (2004: 411-445).

20 Urkiza (2006: 319-380).

21 Weber (2006: 1-19).

22 Martínez Hernández (2009: 31). Redworth (2008: 14-16). 
servidores de las otras casas de la familia real, que habían desaparecido, todos ellos contrarios al partido "castellano", buscaron refugio en la casa de la Infanta.

Un análisis de los curricula confirman su ideología: Los confesores mostraban una tendencia religiosa en sintonía con el movimiento "descalzo": Buenaventura Santibáñez, franciscano del convento de La Aguilera, entre 1581 y 1584, que había sido nombrado confesor de la reina Ana y a la muerte de ésta pasó a desempeñar el cargo con sus hijas; y fray Andrés de la Iglesia entre 1584-1585. También las damas respiraban la misma religiosidad: doña Juana de la Cueva y Mendoza fue dama de Isabel Clara Eugenia hasta 1599, que pasó a la casa de la reina Margarita, donde permaneció hasta 1611, que fue trasladado a la casa de sus altezas y desde 1616 en la de la princesa Isabel de Borbón hasta el 18 de marzo de 1622, cuando se casó con el duque de Terranova ${ }^{23}$. Por su parte, Doña Beatriz de Dietrichtstein y Cardona fue hija del embajador imperial Adam de Dietrichstein, que falleció en Praga en 1590. Su esposa vino a la corte junto a su hija Beatriz y se aposentaron en el convento de las Descalzas Reales junto a la emperatriz María (significativa institución de religiosidad radical). La joven Beatriz fue puesta al servicio de la infanta Isabel Clara Eugenia. Cuando ésta marchó a Flandes, doña Beatriz pasó a servir a la reina Margarita (1599). Se casó con el marqués de Mondéjar en 1600, que se hallaba viudo. Pocos años después, en 1603, doña Beatriz quedó viuda. A partir de entonces mantuvo una asidua correspondencia con su hermano Francisco, cardenal y obispo de Olomuc. En 1614 fundó el convento de carmelitas descalzas de Alcalá de Henares, donde fue enterrada en $1631^{24}$. Doña Jerónima Híjar y de la Cerda, hija de don Cristóbal Fernández de Híjar, conde de Belchite y II duque de Híjar, y de doña Ana de la Cerda y Mendoza, II condesa de Galve. Desde 1591 fue dama de honor de la infanta Isabel Clara Eugenia. Pasó a serlo de la reina Margarita en 1599 hasta que salió casada de palacio con Ruy Gómez de Silva (mayordomo mayor de Felipe III) en $1606^{25}$. La misma evolución se observa en doña Antonia de Toledo y Colonna, hija menor de don Gómez Dávila y Toledo, II marqués de Velada y mayordomo mayor del rey, y de su segunda esposa

23 AGP. Reinados, Felipe III, leg. 1. RAH. Jesuitas, 9/3678, núm. 67 (1).

24 Edelmayer (1993: 89-116). Badura (1999: 47-67). Cruz Medina (2003-2004: 178-180).

25 AGP. Reinados. Felipe III, leg. 1. 
doña Ana de Toledo y Colonna, hija de don García de Toledo, marqués de Villafranca. Fue dama de Isabel Clara Eugenia desde el 18 de febrero de 1596 hasta 1599, que pasó a servir a la reina Margarita hasta el 21 de agosto de 1606 cuando salió de palacio por su matrimonio con don Juan de la Cerda y Aragón, VI duque de Medinaceli y gentilhombre de la cámara, sobrino del duque de Lerma, si bien el mismo Lerma no era muy partidario de este enlace. Era tutora y curadora de la persona y bienes de don Antonio Juan Luis de la Cerda, VII duque de Medinaceli, y de doña Juana de la Cerda, quien estaba concertada de casar en 1603 con el duque de Montalto. Falleció en $1625^{26}$.

\section{Casas de la Reina Ana, de las infantas doña Isabel Clara Eugenia y doña Catalina Micaela (1581-1585) ${ }^{27}$}

(en versalitas, los personajes que se repiten)

\begin{tabular}{|l|l|l|}
\hline $\begin{array}{l}\text { CASA DE LA REINA ANA } \\
(\mathbf{1 5 8 0})\end{array}$ & $\begin{array}{l}\text { CASA ISABEL Y CATALINA } \\
\text { MICAELA (1580-1584) }\end{array}$ & $\begin{array}{l}\text { CASA DE ISABEL Y } \\
\text { PRÍNCIPE FELIPE (1585-98) }\end{array}$ \\
\hline Confesores & Confesores & Confesores \\
\hline Francisco Lillo (1570-74) & $\begin{array}{l}\text { BUENAVENTURA SANTIBÁÑEZ } \\
(1581-84)\end{array}$ & $\begin{array}{l}\text { FRAY ANDRÉS DE LA IGLESIA } \\
(1585-92)\end{array}$ \\
\hline $\begin{array}{l}\text { Francisco de Córdoba } \\
(1574-79)\end{array}$ & $\begin{array}{l}\text { FRAY ANDRÉS DE LA IGLESIA } \\
(1584-85)\end{array}$ & Antonio Cáceres (1592-95) \\
\hline $\begin{array}{l}\text { BuENAVENTURA SANTIBÁÑEZ } \\
(1579-80)\end{array}$ & & Pedro Hernández (1595-97) \\
\hline & & $\begin{array}{l}\text { Gaspar de Córdoba (1597- } \\
98)\end{array}$ \\
\hline
\end{tabular}

\begin{tabular}{|l|l|l|}
\hline Camareras mayores & Camareras mayores & Camareras mayores \\
\hline $\begin{array}{l}\text { Aldonza de Bazán (marque- } \\
\text { sa de Frómista) 1570-72 }\end{array}$ & $\begin{array}{l}\text { FRANCISCA DE ROJAS } \\
\text { (CONDESA DE PAREDES) }\end{array}$ & $\begin{array}{l}\text { FRANCISCA DE ROJAS (CON- } \\
\text { DESA DE PAREDES) 1585-96 }\end{array}$ \\
\hline $\begin{array}{l}\text { Marquesa de Berlanga } \\
(1571-76)\end{array}$ & $\begin{array}{l}\text { Mencía de la Cerda (1585) } \\
\text { Aya de Isabel Clara Eugenia }\end{array}$ & JUANA HACINCURT (1598) \\
\hline $\begin{array}{l}\text { FRANCISCA DE ROJAS (CON- } \\
\text { DESA DE PAREDES) 1576-80 }\end{array}$ & & \\
\hline
\end{tabular}

26 BNE, ms. 2346, fol. 168r. AGP. Sección Registro, libro 6151, fol. 483v, AGP. Administración General, caja 278, exp. 278, AGP. Reinados, Felipe III, leg. 1. RAH. Jesuitas, 9/3678, núm. 67 (1).

27 Martínez Millán y Fernández Conti (2005: II, 674-679). 


\begin{tabular}{|l|l|l|}
\hline $\begin{array}{l}\text { CASA DE LA REINA ANA } \\
\mathbf{( 1 5 8 0 )}\end{array}$ & $\begin{array}{l}\text { CASA ISABEL Y CATALINA } \\
\text { MICAELA (1580-1584) }\end{array}$ & $\begin{array}{l}\text { CASA DE ISABEL Y } \\
\text { PRÍ́NCIPE FELIPE (1585-98) }\end{array}$ \\
\hline Dueñas de honor & Dueñas de honor & Dueñas de honor \\
\hline $\begin{array}{l}\text { María de Dietrichstein (con- } \\
\text { desa de Galve, marquesa de } \\
\text { Navarrés) }\end{array}$ & ANA DE CARDONA (1581-84) & $\begin{array}{l}\text { Isabel Manrique Padilla } \\
\text { (marquesa Montesclaros) }\end{array}$ \\
\hline $\begin{array}{l}\text { FrANCISCA DE RoJAS (CON- } \\
\text { DESA DE PAREDES) 1572-76) }\end{array}$ & $\begin{array}{l}\text { JUANA ENRÍQUEZ DE } \\
\text { MENDOZA (1581-85) }\end{array}$ & $\begin{array}{l}\text { María Bazán (condesa de } \\
\text { Uceda) }\end{array}$ \\
\hline $\begin{array}{l}\text { Juana de Cárdenas (1573- } \\
80)\end{array}$ & $\begin{array}{l}\text { ANA MANRIQUE (CONDESA } \\
\text { PUÑOENROSTRO (1581-85) }\end{array}$ & \\
\hline $\begin{array}{l}\text { Catalina Lasso de Castilla } \\
(1573-i)\end{array}$ & $\begin{array}{l}\text { INÉS MANRIQUE (CONDESA } \\
\text { PUÑOENROSTRO), 1581-83 }\end{array}$ & \\
\hline ANA DE CARDONA (1573-80) & Sancha de Guzmán & \\
\hline $\begin{array}{l}\text { Marquesa de Ladrada } \\
(1574-80)\end{array}$ & HIPÓLITA DE DIETRICHSTEIN & \\
\hline $\begin{array}{l}\text { FRANCISCA MANRIQUE } \\
(1577-80)\end{array}$ & & \\
\hline Leonor Chacón (1570-80) & & \\
\hline
\end{tabular}

\begin{tabular}{|c|c|c|}
\hline Damas & Damas & Damas \\
\hline Isabel Chacón (1570-80) & $\begin{array}{l}\text { ISABEL DE LA CUEva (1581- } \\
85 \text { ) }\end{array}$ & $\begin{array}{l}\text { ISABEL DE LA CUEVA (1581- } \\
85 \text { ) }\end{array}$ \\
\hline JUANA HACINCURT (1570-80) & JUANA HACINCURT (1581-85) & JUANA HACINCURT (1585-98) \\
\hline $\begin{array}{l}\text { ANA MANRIQUe (CONDESA } \\
\text { PuÑOENROSTRo }(1570-80)\end{array}$ & $\begin{array}{l}\text { FRANCISCA MANRIQUE } \\
(1581-85)\end{array}$ & JuANA MANRIQUE (1585-92) \\
\hline Ana de Navarra (1570-79) & JuANA MANRiQue (1581-85) & $\begin{array}{l}\text { JuANA ENRÍQUEZ DE } \\
\text { MENDOZA (1573-80) }\end{array}$ \\
\hline CLAUdia TURIÑI (1570-80) & CLAudia TuRIÑI (1581-84) & \\
\hline $\begin{array}{l}\text { Catalina Sandoval (1572- } \\
1575)\end{array}$ & IsABEL GoNZAGA (1583-85) & IsABEL GoNZAGA (1585-93) \\
\hline $\begin{array}{l}\text { Catalina de Zúñiga (1572- } \\
\text { 1575) }\end{array}$ & Luisa Manrique & $\begin{array}{l}\text { ANA MANRIQUe (CONDESA } \\
\text { PuñoenRostro (1585-92) }\end{array}$ \\
\hline $\begin{array}{l}\text { Estefanía Carrillo Mendoza } \\
(1572-77)\end{array}$ & MaRiana MENDOZA & $\begin{array}{l}\text { MaRiana MENDOZa (1586- } \\
94)\end{array}$ \\
\hline María de Cardona & Catalina Zapata & $\begin{array}{l}\text { Isabel Mejía Guzmán } \\
(1589-97)\end{array}$ \\
\hline Ana de la Cerda & ISABEL MENDOZA & María Meneses (1590-97) \\
\hline Catalina de la Cerda & & $\begin{array}{l}\text { Francisca Mendoza (condesa } \\
\text { de Palma) 1591-94 }\end{array}$ \\
\hline María de Córdoba & & Jerónima Híjar (1591-97) \\
\hline ISABEL DE LA CUEVA & & $\begin{array}{l}\text { Margarita de Sosa y Tabora } \\
(1593-97)\end{array}$ \\
\hline
\end{tabular}




\begin{tabular}{|l|l|l|}
\hline $\begin{array}{l}\text { CASA DE LA REINA ANA } \\
\text { (1580) }\end{array}$ & $\begin{array}{l}\text { CASA ISABEL Y CATALINA } \\
\text { MICAELA (1580-1584) }\end{array}$ & $\begin{array}{l}\text { CASA DE ISABEL Y } \\
\text { PRÍNCIPE FELIPE (1585-98) }\end{array}$ \\
\hline Damas & Damas & Damas \\
\hline Isabel Laso & & $\begin{array}{l}\text { Juana Cueva Mendoza } \\
\text { (1594-97) }\end{array}$ \\
\hline Luisa Lasso & $\begin{array}{l}\text { Elvira Zúñiga Mendoza } \\
\text { (1595-97) }\end{array}$ \\
\hline María Lasso & & Mariana Mújica (1596-97) \\
\hline Hipólita de Mendoza & $\begin{array}{l}\text { BEATRIz DiETRICHSTEIN Y } \\
\text { CARDONA }\end{array}$ \\
\hline $\begin{array}{l}\text { JUANA ENRÍQUEZ DE } \\
\text { MENDOZA (1573-80) }\end{array}$ & & Mariana de Rojas \\
\hline Guiomar de Melo & & $\begin{array}{l}\text { Juana de Sandoval (duquesa } \\
\text { Medinasidonia) }\end{array}$ \\
\hline María Pimentel (1575-76) & & Ana de Velasco \\
\hline INÉS MANRIQUE (1575-80) & & \\
\hline JuANA MANRIQUE (1576-80) & & \\
\hline Isabel de Sa (1576-78) & & \\
\hline Luisa Manrique (1577-80) & & \\
\hline $\begin{array}{l}\text { IsABEL De MeNDOZA (1577- } \\
80)\end{array}$ & & \\
\hline Luisa Fajardo (1578-80) & & \\
\hline Guiomar de Sa (1579-80) & & \\
\hline
\end{tabular}

\begin{tabular}{|l|l|l|}
\hline Guardamayor de damas & Guardamayor de damas & Guardamayor de damas \\
\hline Teresa de Guevara (1572) & Francisca Alarcón (1581-85) & Antonia Branchez \\
\hline $\begin{array}{l}\text { MARÍA MANRIQUE (MARQUE- } \\
\text { SA DE CENETE) 1576-77 }\end{array}$ & María de Ovando (1581-85) & MARÍA MANRIQUE (1591-97) \\
\hline
\end{tabular}

\begin{tabular}{|l|l|l|}
\hline Mayordomo mayor & Mayordomo mayor & Mayordomo mayor \\
\hline $\begin{array}{l}\text { Antonio de la Cueva } \\
\text { (I marqués de la Ladrada } \\
(1570-74)\end{array}$ & $\begin{array}{l}\text { FRANCISCO ZAPATA DE } \\
\text { CISNEROS (I CONDE DE } \\
\text { BARAJAS) 1580-85 }\end{array}$ & JUAN DE ZÚÑIGA (1586-87) \\
\hline $\begin{array}{l}\text { Juan de la Cerda (IV duque } \\
\text { de Medinaceli) 1574-75 }\end{array}$ & JUAN DE ZÚÑIGA (1585) & $\begin{array}{l}\text { Gómez Dávila Toledo } \\
\text { (II marqués de Velada) } \\
1587-98\end{array}$ \\
\hline $\begin{array}{l}\text { Pedro Fajardo (III marqués } \\
\text { de los Vélez (1575-78) }\end{array}$ & & \\
\hline $\begin{array}{l}\text { FRANCISCO ZAPATA DE } \\
\text { CiSNEROS (I CONDE DE } \\
\text { BARAJAS) 1579-80 }\end{array}$ & & \\
\hline
\end{tabular}


Doña Isabel Mejía y Guzmán, hija del conde de Uceda, entró como dama de la infanta Isabel Clara Eugenia en abril de 1589 y después de la reina Margarita en 1599. Salió casada de palacio en $1600^{28}$. Doña Juana Enríquez de Mendoza fue dama de la infanta Isabel Clara Eugenia desde 1585 y pasó a servir a doña Margarita de Austria en 1599 hasta que salió casada de palacio en $1603^{29}$. Doña Juana de Sandoval y Rojas, hija del V marqués de Denia y I duque de Lerma, fue condesa de Niebla por su matrimonio con don Juan Manuel Pérez de Guzmán el Bueno (XI conde de Niebla, 1579-1636), heredero y sucesor del ducado de Medina Sidonia; fue dama de honor de la infanta Isabel Clara Eugenia. Juana Hazincourt aparece como dama de la casa de la reina Ana de Austria y, a su muerte en 1580, como dama de honor de la infanta Isabel Clara Eugenia entre 1581 y 1598, año en que fue nombrada camarera mayor y marchó a Flandes con la infanta hasta 1613 en que fue sustituida por la condesa de San Víctores ${ }^{30}$.

El 21 de junio de 1587, Felipe II ordenaba al conde de Chinchón de formar una misma casa para la infanta Isabel Clara Eugenia y para el príncipe Felipe, dado que éste aún tenía pocos años de edad. Ciertamente, fue a partir de entonces cuando se observa la influencia que el "partido papista" (que comprendía las elites sociales opuestas al grupo "castellano") estaba alcanzando en la corte hispana, pero también los cambios que se estaban produciendo en la organización administrativa de la Monarquía y la configuración del papado, apareciendo como una monarquía absoluta ${ }^{31}$. El 30 de enero de 1594, Borghese era recibido por Felipe II y, por consejo del secretario Juan de Idiáquez, se limitó a la mera presentación del breve credencial, dejando para una segunda entrevista el tratamiento de los temas que traía en sus instrucciones. Mientras tanto, el legado pontificio aprovechó para visitar al príncipe Felipe, a su hermana Isabel Clara Eugenia, al cardenal archiduque Alberto y a la emperatriz María para que todos ellos intercedieran ante el rey para conseguir pronta y favorable resolución en todos sus asuntos, especialmente en el de los turcos. La lista de servidores del príncipe Felipe y de la infanta Isabel Clara Eugenia ${ }^{32}$. El 16 de septiembre 1598 el patriarca de Alejandría señalaba al cardenal Aldobrandini la

28 AGP. Personal, caja 663/19. AGP. Reinados. Felipe III, leg. 1.

29 AGP. Reinados. Felipe III, leg. 1.

30 Thomas y Duerloo (1999: 107-119).

31 Prodi (1982)

32 RAH. Jesuitas 9/3661, doc. 121, reproducido en Martínez Millán (1999: III, 157-162). 
estrecha unión que existe entre el joven rey y su hermana y de éstos con la emperatriz María, a quien han ido a visitar ${ }^{33}$. E1 25 de septiembre de 1598, el nuncio visitó a la Emperatriz, que se encontraba en las Descalzas Reales, y aprovechó para exhortarle a que interviniese ante el rey, su nieto, en favor de la Santa Sede ${ }^{34}$.

Desde la designación del marqués de Velada como mayordomo mayor de Isabel Clara Eugenia (el 9 de agosto de 1587), fueron muy estrechas las relaciones políticas y personales establecidas entre ambos. Velada había regresado de nuevo a la corte, después de una década de ausencia, para hacerse cargo de la casa de los dos hijos del monarca que aún permanecían solteros y para ello había contado con el valioso apoyo de Cristóbal de Moura y de su propio hermano, Fernando de Toledo, gentilhombre de cámara del rey, que había alcanzado gran influencia sobre el monarca. El marqués de Velada se encargó personalmente de enviar los objetos y enseres de Isabel, que no pudieron ser embarcados en Barcelona con destino a Flandes antes de su marcha. Así, en la relación que el guardajoyas Hernando de Rojas hizo llegar a Velada a finales de septiembre de 1600, se recogía lo que queda pendiente de remitir y lo que ya se ha enviado.

Poco antes de la muerte de Felipe II, un importante personaje venía a engrosar el grupo de la infanta Isabel Clara Eugenia: la reina Margarita de Austria. En su afán de mantener los reinos unidos y de buscar la preeminencia de la dinastía, Felipe II ordenó casar a su hijo con alguna de sus primas del Imperio. La elegida fue Margarita, nacida en Gratz el 25 de diciembre de 1584. Cuando la archiduquesa recibió la noticia de su matrimonio se hallaba asistiendo a los enfermos en el hospital de Gratz. Aunque sus biógrafos han utilizado esta noticia en tono apologista ${ }^{35}$, tal práctica de caridad no constituía un hecho aislado en su vida, sino que era fruto del modo de entender la espiritualidad católica y la educación religiosa que había recibido dentro de su familia, tan radical como la practicada en las órdenes "descalzas". Su padre, el archiduque Carlos, había asumido una espiritualidad católica radical frente al ambiente protestante que le rodeaba, siendo educado por los jesuitas que Aquaviva había enviado ${ }^{36}$.

33 ASV. Spagna SS, lib. 49, fol. 289r-290r.

34 Ibid., fol. 307-311.

35 Esta imagen piadosa es la que ha sido mostrada por sus apologistas. Sánchez (1996: 96).

36 «Fue de singular ayuda y provecho para esto [espiritualidad de Margarita] el admitir en Gratz los padres de la Compañía». Guzmán (1617: 7v). 
La misma espiritualidad era compartida por su hijo, el futuro emperador Fernando II (1578-1637), hermano de la reina Margarita de Austria.

La sintonía ideológica y espiritual de Isabel Clara Eugenia y Margarita era tan grande que, cuando la Infanta contrajo matrimonio con su primo el archiduque Alberto, los servidores de su casa pasaron servir de manera natural a la reina Margarita de Austria, cuya espiritualidad radical era bien conocida. He podido contabilizar más de cuarenta personajes que cambiaron de casa, entre los más representativos, se encontraban: doña Antonia de Abranches, dama portuguesa, Guarda mayor de las damas de las infantas Isabel Clara Eugenia y Catalina Micaela hasta 1585, cuando al partir ésta última para la corte de Saboya, pasó a servir al príncipe Felipe y a Isabel Clara Eugenia, si bien las quejas ante su servicio por parte del marqués de Velada obligaron al monarca a sustituirla por doña María Manrique. En 1599 fue recibida en la casa de la reina, sirviendo al menos hasta 1610. Se hizo monja profesa en la Concepción Francisca de Madrid ${ }^{37}$. Doña Beatriz Cardona, hija de don Adam de Dietrichteim, embajador imperial, y de doña Margarita de Cardona, dama que fue de la emperatriz María, fue dama de Isabel Clara Eugenia hasta 1599, cuando a comienzos de mayo fue asentada en los libros de la reina Margarita, donde permaneció hasta el 10 de febrero de 1600, cuando salió casada con el marqués de Mondéjar. Solicitó entrar en las Descalzas para servir a la emperatriz María ${ }^{38}$. Lo mismo sucedió con Antonia de Figueroa, guarda menor de las damas de la casa de la infanta Isabel Clara Eugenia hasta el primero de mayo de 1599 cuando se la asentó en la casa de la reina Margarita, donde sirvió hasta $1611^{39}$. Asimismo, doña Jerónima Híjar de la Cerda (IV condesa de Galve), hija de don Juan Cristóbal Fernández de Híjar, duque de Híjar y conde de Belchite ${ }^{40}$.

Doña María Manrique fue guardamayor de la casa de Isabel Clara Eugenia en lugar de la portuguesa doña Antonia de Abranches, de donde

37 Tenía de gajes anualmente, por cédula de Felipe II, 500.000 mrs, con claúsula de que pudiese renunciar esta cantidad en la persona que desease, para que los gozase durante toda su vida. Abuela de doña Margarita de Mendoza, dama de la princesa Isabel de Borbón. AGP. Administración General, caja 10.278. RAH. Jesuitas, 9/3678, núm. 67 (1). Martínez Hernández (2004: 287).

38 AGP. Reinados, Felipe III, leg. 1. RAH. Jesuitas, 9/3678, núm. 67 (1). AGS. E, leg. 180, s.f. Sánchez (1998: 89).

39 AGP. Administración General, leg. 632; AGP. Sección Histórica, caja 190.

40 AGP. Reinados, Felipe III, leg. 1. AGS. CJH, leg. 485, núm. 16-63-1. RAH. Jesuitas, 9/3678, núm. 67 (1). 
pasó a dueña de honor de la reina Margarita desde el 1 de mayo de 1599 hasta $1611^{41}$. Doma María Meneses fue una dama portuguesa de la infanta Isabel Clara Eugenia, al menos, desde 1588 hasta el primero de mayo de 1599 cuando fue asentada en los libros de la casa de la reina Margarita, donde permaneció hasta el 31 de enero de 1606, cuando salió casada con don Simao Rodrigues da Cámara, III conde de Calheta ${ }^{42}$. Los mismo que doña Margarita Tavora, también dama portuguesa, sobrina de don Cristóbal de Moura e hija de Álvaro de Sousa, I señor del Morgado de Alcube, y de Francisca de Távora. Fue dama de la infanta Isabel Clara Eugenia, quedando tras su partida en Castilla como dama de la reina Margarita desde el primero de mayo de 1599 hasta el 5 de febrero de 1600, pocos días después de que a su tío se le nombrase virrey de Portugal, cuando salió casada de palacio con don Martim Alfonso de Castro, virrey de la India y gentilhombre de la boca de Felipe III, hijo segundo de António de Castro, IV conde de Monsanto y couteiro mayor de Felipe II, y de doña Inés Pimentel ${ }^{43}$. Parecida evolución tuvo doña Antonia Toledo y Colonna, hija menor de don Gómez Dávila y Toledo, II marqués de Velada y mayordomo mayor del rey, y de su segunda esposa doña Ana de Toledo y Colonna, hija de don García de Toledo, marqués de Villafranca. Fue dama de Isabel Clara Eugenia desde el 18 de febrero de 1596 hasta 1599, cuando desde el primero de mayo fue asentada en los libros de la casa de la reina Margarita ${ }^{44}$.

En la «nómina de gajes de los criados y criadas de sus Altezas [Felipe e Isabel Clara Eugenia] del tercio postrero del año mil quinientos noventa y siete» se puede apreciar que los personajes que ocupaban los principales oficios no procedían del grupo castellano ${ }^{45}$ : aparecían García de Loaysa como maestro del príncipe, cuya vinculación con el papa ya se ha señalado, fray Gaspar de Córdoba como confesor; como mayordomos, el marqués de

41 RAH. Jesuitas, 9/3678, núm. 67 (1). AGP. Administrativa General, leg. 631.

42 El 25 de mayo de 1600 se trató de su matrimonio con el portugués don Luís da Silveira, III conde de Sortelha, guarda mayor de la casa real portuguesa. AHN. Estado, libro. 81, fol. 17r. AGS. SP. Portugal, libro. 1486, fol. 144v. AGP. Reinados, Felipe III, leg. 1. RAH. Jesuitas, 9/3678, núm. 67 (1).

43 AGP. Reinados, Felipe III, leg. 1. RAH. Jesuitas, 9/3678, núm. 67 (1). PérezMinguez (1934: 272).

44 BNE. Mss. 2346, fol. 168r. AGP. Sección Registro, libro 6151, fol. 483v, Personal, caja 278; Reinados, Felipe III, leg. 1. RAH. Jesuitas, 9/3678, núm. 67 (1).

45 RAH, Jesuitas, leg. 9/3678, exp. 48, publicado en Martínez Millán (1999a: 155-160). 
Velada $^{46}$, el conde de Orgaz, don Fernando Henríquez de Rivera (marqués de Villanueva), todos ajenos a la facción castellana del reinado de Felipe II, apreciación que se ratifica cuando observamos las damas que servían a la Infanta: la condesa de Uceda y la marquesa de Monstesclaros, María Manrique, Juana Jacincourt, Mariana de Rojas, Elvira de Zúñiga, Victoria Colonna, Isabel Mexía, María de Meneses, María de Ovando, etc.

\section{ENTRE LA OBLIGACIÓN POLÍTICA Y LA CONVICCIÓN RELIGIOSA (1599-1621)}

Aunque los planes de matrimonio de la infanta Isabel Clara Eugenia fueron numerosos, alimentados por la situación en guerra en que Europa se encontraba y un matrimonio era considerado una acción de política exterior, Felipe II optó por casar a su hija con su sobrino el archiduque Alberto y enviarlos como gobernadores de unos territorios patrimoniales ${ }^{47}$. El Acta de cesión (6 mayo 1598) constituyó el fundamento en el que se basó el matrimonio de Isabel y el archiduque Alberto. En dicho documento se declaraba que la dote de la Infanta consistía en los Países Bajos (las diecisiete provincias) y el Franco Condado (que llevaba unido el condado de Charolais). Es importante recordar que estos territorios pertenecían al Sacro Imperio excepto Charolais, feudo de Francia. EL Acta contenía algunas cláusulas secretas referidas, sobre todo, a temas de religión: sólo los católicos podían ser servidores de la casa de los gobernadores; los monarcas españoles eran los garantes de la paz en los Países Bajos, etc. ${ }^{48}$ La importancia de tales territorios para los reyes hispanos era muy grande y no tanto por su situación estratégica cuanto porque representaban la cuna de la dinastía y renunciar a ellos representaba una contradicción política existencial; de hecho, como explica P. Allen, una vez otorgado el gobierno a los Archiduques, Felipe III estuvo arrepentido y prefería concederles la corona de Portugal, que la consideraba de importancia inferior, a pesar de su gran extensión por todo el mundo ${ }^{49}$.

Desde que estallara la revuelta en los Países Bajos a causa de las reformas que llevó a cabo Felipe II, cuando comenzó a configurar administrati-

\footnotetext{
46 Martínez Hernández (2004: 245-267).

47 Lonchay (1910: 364-88). García Prieto (2009: 131-153).

48 Duerloo (2012: 65-68).

49 Allen (2001: 50-52).
} 
vamente su Monarquía (dejando fuera a gran parte de las elites flamencas), las relaciones históricas entre ambas entidades siempre se han enfocado desde un aspecto bipolar, en la que los Países Bajos pretendían la independencia mientras la corte de Madrid aparece como la Monarquía opresora que trataba de impedir la ruptura ${ }^{50}$. De esta manera, la actividad política y social del matrimonio (infanta Isabel Clara Eugenia y archiduque Alberto) desde que marchó a Flandes se ha trazado desde la dialéctica de la influencia que la corte de Madrid ejerció sobre los Gobernadores y sus servidores para mantener la unión ${ }^{51}$. No resulta extraño que la idea creada por Joseph Lefèvre, en 1923, de "partido español" (ministère espagnol) para designar al grupo de servidores que Felipe III tenía en Flandes junto a los archiduques para imponer sus planes políticos, haya tenido tanto éxito. La preocupación de que estos territorios estuvieran subordinados o conectados con Madrid, llevó a buscar la manera de introducir en la casa archiducal servidores hispanos o flamencos que compartieran los intereses de la corte hispana ${ }^{52}$. Un estudio de los servidores de la casa de los Archiduques demuestra que el grupo de españoles representó una parte muy importante de todos ellos: durante los primeros años de gobierno (entre 1598 y 1605) superó la mitad (llegó al $67.8 \%$ ), a partir de 1605 hasta 1621 la proporción disminuyó (concretamente el 37 o $38 \%)^{53}$.

La pugna entre las elites sociales de los Países Bajos y la corte de Madrid fue complicándose con el paso del tiempo, las razones del enfrentamiento que se esgrimían en el siglo XVII eran bastante diferentes de las que habían originado la revuelta de los Países Bajos a mitad del siglo XVI, y puso al descubierto los diversos factores que concurrían en la existencia de aquellos territorios, que ayudan a comprender la situación conflictiva, imposible de reducir a una bipolaridad ${ }^{54}$. De cualquier manera, siempre existió una especie de recelo o desconfianza de Madrid hacia el comportamiento de los Archiduques, pensando que éstos se dejan convencer por los consejeros flamencos, lo que provocaba una cierta independencia con respecto a Madrid. El 27 de agosto de 1616, Isabel Clara Eugenia escribía

50 Carter (1964: 251-258). Diagre (1995: 117-128).

51 De hecho, los soberanos del territorio no controlaban los nombramientos, incluso a veces ni siquiera eran informados por parte de la corte de Madrid, Schepper y Parker (1976: 241-253). Esteban Estríngana (2002: 94-96).

52 Lefèvre (1923: 64-71). Israel (1997: 1-22).

53 Thomas (2014: 172-173).

54 Carter (1964: 245-259). 
una carta a su hermano Felipe III en la que le ponía claro el gobierno que estaban realizando y por su interés la transcribo entera:

Señor, habiendo mi primo [Alberto] resuelto de enviar a su confesor a representar a V. M. algunas cosas que le tocan, en que va harto del servicio de V. M., yo, como tan interesada en lo uno y en lo otro, no puedo dejar de suplicar a V. M. mande poner remedio en ellas de manera que no tengamos ocasión de cansar cada día a V. M., que es lo que más siento; y que mi primo, que no se desvela en otra cosa sino en procurar el servicio de V. M., tenga para poderle hacer la autoridad que es justo que aunque de ninguna manera yo dudo en la merced que V. M. nos hace y desea hacer. Las órdenes que llegan acá algunas veces son de manera que estoy bien cierta que V. M., con lo mucho que tiene en qué atender, lo remite a sus ministros que, aunque creo que deben desear de acertar, no lo hacen como sería menester. Y así, torno a suplicar a V. M. lo mande remediar con seguridad de que no hay en el mundo quien desee más el servicio de V. M. que nosotros y por esta razón no puedo de dejar de decir a V. M. cómo habemos entendido que el marqués de Spínola ha suplicado a V. M. le dé licencia para irse, y esto sería grandísimo perjuicio al servicio de V. M. como dirá más particularmente el confesor, a quien hemos encargado que suplique a V. M. no lo consienta, sino que le haga merced para que se sosiegue. Pues cierto yo entiendo se irá la perdición del ejército no estando mi primo con pies para poder acudir a él, y así no puedo de dejar de decir esto a V. M. a quien el confesor dará las nuevas que quisiere saber de acá ${ }^{55}$.

Es preciso insistir en que, a pesar de los intentos que hubo en configurar un "Estado independiente" 56 , los Países Bajos no eran unos territorios cualquiera dentro de la Monarquía hispana, eran territorios vinculados al origen de la casa Habsburgo, Felipe el Hermoso y, posteriormente, su hijo, el archiduque Carlos, habían organizado su servicio desde allí (Casa de Borgoña con servidores flamencos) y lo llevaron a Castilla en 1506 y 1517 respectivamente. Esta fidelidad a la dinastía motivó que Carlos V impusiera la casa de Borgoña no solo para él, sino también para su hijo Felipe II (en 1548), prefiriéndola por encima de las demás casas que poseían los reinos y territorios que conformaban su Monarquía, a pesar de que algunos reinos fueran más poderosos, en los que se apoyaron para ejercer su

55 AGS. E, leg. 8816. Isabel a Felipe III, La Bura, 27 de agosto 1616.

56 Valladares (1999: 47-54). Bonafont (1935-36:151-169). 
política e, incluso, para establecer su residencia continua, como así sucedió con la Corona de Castilla.

Para comprender con exactitud el alcance de esta decisión, se debe recordar que la organización política en la que nos movemos en esta época era la Monarquía (patrimonial), no bajo el concepto de "Estado"; por consiguiente, el concepto "casa" es sinónimo de "dinastía", cuya aspiración es perpetuarse en el tiempo. Para Pierre Bourdieu, decir que la "casa real tenía como política estrategias domésticas quiere decir que se describen como políticas cosas que no son políticas". Las estrategias matrimoniales estaban inspiradas en la preocupación de perpetuar la casa, pues la distinción entre la dinastía y el aparato del Estado aún no se había realizado ${ }^{57}$.

\section{1. Los servidores de Isabel Clara Eugenia en Flandes}

La casa de los Archiduques seguía la misma distribución que la casa del rey de España, no solo porque ambas eran la casa de Borgoña, sino también porque es preciso recordar que el archiduque Alberto ya tenía la casa fijada en 1595 cuando Felipe II lo envió como gobernador de los Países Bajos $^{58}$. No obstante, cuando el matrimonio marchó a Flandes, la casa de Borgoña iba más nutrida de servidores, no solo por la cantidad de mujeres y servidores que acompañaron a Isabel, sino también porque tanto el difunto Felipe II como el nuevo rey (Felipe III) se encargaron de introducir nuevos personajes que mirasen por los intereses de la Monarquía y también porque acoplaron a determinados servidores de otras casas a quien había que acoplar. Lo que aparece evidente es que en la lista de servidores que acompañaron a los Archiduques para servirlos en Flandes (1599), la gran mayoría eran castellanos y que paulatinamente (una vez en Flandes) se fueron introduciendo numerosos flamencos; la aristocracia local no hizo sino crecer. No obstante, los castellanos se sentían el grupo que debía articular la

57 La forma de gobierno que los Archiduques mantenían, eran muy similares a las del monarca hispano. Se pasaban residiendo en los diversos sitios reales y controlaban toda la población mostrándose cercanos e impulsando las fiestas: «Para san Andrés nos venimos aqui pesándonos harto dejar la Bura con las trazas que aún no están acabadas por andar midiendo lo que ha de ser parque. Enviaré unas fiestecillas que se hicieron alli para entretener un rato a $V$. M. qu ninguna cosa que sea de gusto me entra en provecho si V. M. no goza de ello, aunque no sea sino por escrito». Isabel a Felipe III, carta fechada en Bruselas a 7 diciembre 1616 (AGS. E, leg. 8816).

58 Ha sido estudiada por Hortal Muñoz (2013: 1011-1056). También, Hortal Muñoz y Labrador Arroyo (2014). 
Monarquía, por lo que se consideraban la elite dirigente y los que debían mantener unidos todos los reinos: Alonso de Melo, gentilhombre de la boca de Alberto, fue premiado con la distinción de la Orden de Cristo, pero rechazó el honor porque era orden portuguesa y él era castellano ${ }^{59}$.

Raeymaekers ${ }^{60}$ ha descubierto varios listados de servidores que confirman esta evolución. Según esta historiadora, el número de componentes de la casa en 1595, comparado con los que arrojan dos listados fechados en 1605, aumentó en más de un centenar. Este crecimiento de cargos y servidores ayuda a comprender que, poco tiempo después de llegar Alberto a Bruselas ${ }^{61}$ modificase arquitectónicamente la distribución de su residencia, en el palacio de Coudenberg, con el fin de articular y distribuir los espacios cortesanos en orden a dar mayor dignidad y lejanía a su persona y a la de su esposa, pero también para fijar la categoría y gradación de los diferentes cargos para lo que era necesario redistribuir los espacios y señalar qué cargos podían moverse en cada $u^{6}{ }^{62}$. El crecimiento del número de servidores fue constante durante todo el tiempo de su gobierno como se constata a partir de 1612, cuando las relaciones de servidores resultan más claras y fiables dado que el tesorero del Archiduque realizaba cada cuatro meses la nómina de los que debían cobrar sus salarios. Según tales listados, en 1612 la casa pagaba a 344 sirvientes y durante el período entre enero y abril de 1614, la cifra ascendió a 364 servidores; en los mismos meses del año 1618 la cifra era de 390, a los que habría que sumar el personal de la capilla y de las guardas, que iban separados, en total 566 servidores $^{63}$. Para nuestro propósito (y dado el espacio que dispongo), me voy a fijar en los servidores específicos de la Infanta.

Por lo que respecta al servicio que Isabel Clara Eugenia llevó a Bruselas, estaba compuesto por mujeres hispanas; una vez allí, entabló confianza y amistad con damas procedentes de diversas familias nobles de aquellos territorios. Si tal evolución puede resultar lógica y normal, sobre todo si además se quiere atraer a las elites de los reinos sublevados, existen razones profundas que explican tanto unas como otras pertenecían al mismo grupo, compartían una misma ideología y espiritualidad que, por supuesto,

Duerloo (2012: 97).

Raeymaekers (2007: I, 1078-1079).

Raeymaekers, (2013: Passim); Raeymaekers (2009: 264-265).

Villermont (1912: II, 40-45). Jonge (1998: 191-215).

Martínez Millán y Visceglia (2007: 1079-1080). 
no coincidía con la "castellana" en la que se había educado Isabel Clara Eugenia. Con todo, Isabel Clara Eugenia tenía las ideas muy claras acerca de cómo debía estructurar su casa. En 1616 escribía a su hermano Felipe III comentándole la decisión que había tomado en relación con las servidoras de su hija Ana de Austria, reina de Francia, y a propósito comenta lo que ella realizó cuando llegó a Flandes:

Muy buena resolución ha tomado V. M. en que vuelvan las españolas quedando solo las que son menester para el servicio de la reina, porque sin duda no somos las españolas para la libertad de por acá y más para la de Francia, y no hay que pensar que se puedan acomodar unas con otras. Y aunque yo pienso haber hecho ese milagro en mi casa, ha sido con mucho trabajo y tiempo, y aun Dios sabe si allá dentro se tragan, y para la reina puede dejar de ser mucha pesadumbre verlas mal avenidas ${ }^{64}$.

De cualquier manera, Isabel estaba convenida de que los mejores servidores, para no levantar enfrentamientos, eran los personajes del propio reino ${ }^{65}$.

El personaje de mayor influencia castellano que tuvo Isabel en Flandes fue, sin duda, su confesor, el franciscano Andrés de Soto (1553-1625). Como confesor, diplomático y comisionado general de Isabel para la orden franciscana en las "naciones germanas" de Soto gozó de gran influencia en la corte y en el mundo de la política. Aparece en el grabado que realizó Cornelius Galle del cortejo fúnebre del Archiduque Alberto como un hombre demacrado, de aspecto ascético, que se distingue de todos los demás participantes en la procesión por sus ojos humildemente abatidos, ejemplo de ideales espirituales franciscanos ${ }^{66}$. La obediencia de la

64 Carta de Isabel a Felipe, fechada en Bruselas el 18 de diciembre 1616 (AGS. E, leg. 8816)

65 De Bruselas á 29 de Enero 1601, escribía una carta al duque de Lerma en la que le expresaba la recomendación que le hacía don Baltasar con un papel de doña Juana de Mendoza sobre su pretensión; "y no dexa de espantarme de la manera que habla, en que le tuvimos hecha merced de recibilla, pues como vos sabéis mejor que nayde, nunca se llegó á este término; y yo dende que salí de ay, determiné de servirme de las de acá, por ser esto lo que mejor nos estaba, por muchas razones. La voluntad de doña Juana me obliga mucho, y así os pido que de mi parte supliquéis á mi hermano con mucho encarecimiento haga merced á doña Juana en todo lo que se le ofreciere». Rodríguez Villa (83).

66 Wyhe (2004: 441-446). 
Infanta a su confesor se evidenció en su adopción del hábito franciscano poco después de la muerte del Archiduque. La subordinación obediente de las princesas a su confesor era considerada por los contemporáneos como ejemplo de virtuosismo femenino y con frecuencia era objeto de elogios. Miræus lo describió como el director y árbitro de la conciencia de la Infanta y Philippe Chifflet, sacerdote del oratorio Archiducal, dedicó un capítulo entero en su biografía inacabada de la Infanta a Andrés de Soto, señalando que le había escrito diversos tratados de devoción ${ }^{67}$.

Una vez en Bruselas, el contexto político y social indujo a que numerosas mujeres, pertenecientes a las familias más poderosas de los Países Bajos, entrasen a formar parte del entorno más cercano de la Isabel. Es preciso insistir en que no fue solo la procedencia social lo que impulsó a Isabel Clara Eugenia a incorporar a estas mujeres en su entorno y amistad, sino además porque todas ellas seguían las mismas ideas y practicaban la misma espiritualidad, muy distinta de la religiosidad "castellana" ${ }^{98}$. Cordula van White ha estudiado la espiritualidad que se practicaba en la cámara de Isabel, que era la "descalza" ${ }^{69}$. Por su parte, Duerloo destaca la devoción a la Eucaristía que comenzó a surgir y la leyenda de Rodolfo ${ }^{70}$.

Siguiendo la estructura de la casa real, se observa que la camarera mayor era la autoridad de la cámara (el equivalente al sumiller de corps en la cámara del Archiduque) ${ }^{71}$, de ella dependían todos los oficios y cargos, fueron: Jeanne de Chassincourt (1598-1612), hubo un período vacante de tres años (1612-1615), Antoinette Guillemette de Arenberg (1615-1626) ${ }^{72}$.

Jeanne de Chassincourt era una dama de ascendencia francesa, amiga de la duquesa de Aarschof (Ana de Crö̈) hasta el punto de que en sus cartas se dirigía como "mi hermana". Parece que ya estuvo sirviendo en la casa de las infantas Isabel y Catalina Micaela, hijas de Felipe II, partiendo con la infanta Isabel Clara Eugenia para Bruselas en 159973. Gracias a

67 Wyhe (2001: cap. $\left.4^{\circ}\right)$.

68 Duerloo (2012: 35-47).

69 Wyhe (2005: 951-980). Afirma que en la cámara de Isabel «vivían como en un claustro» (p. 957)

70 Duerloo (1999: 268-274).Poco después surgió la leyenda en España, Martínez Millán y Rivero Rodríguez (2017, III/1: 75-87).

71 Houben y Raeymaekers (2014: 125-145).

72 Raeymaekers (2017: 183).

73 W. Thomas, (2014: 182). 
Isabel Clara Eugenia vivió con gran solvencia económica hasta el punto de que cuando murió en 1614, se le encontraron la cantidad de 200.000 escudos. Antoinette Guillemette de Arenberg era la hermana del conde de Arenberg. Murió a la edad de 70 años. Su familia trasladó su cuerpo a Francia y lo enterró en La Châtre en Berry, región donde había nacido.

Antoinette Guillemette de Arenberg gozó de mayor influencia que la anterior, sobre todo tras la muerte de Alberto, cuando la cámara del archiduque desapareció y la camarera mayor y las dueñas de honor de la Infanta, que en su mayoría eran del sur de los Países Bajos (Margarita de Lille, condesa de Buquoy; Madame de Pallant, Madame de Roisin, etc. ${ }^{74}$, gozaron de la plena confianza de Isabel y la influencia que ejercieron sobre ella resultó muy evidente. De hecho, la camarera mayor ejerció su íntima relación con Isabel para obtener numerosas mercedes a favor de familiares y $\operatorname{amigos}^{75}$.

Con todo, es preciso señalar que la espiritualidad de la Infanta se hizo mucho más radical cuando se asentó en Bruselas, no solo por el catolicismo practicado en los Países Bajos, sino también por el que vivían los numerosos grupos de refugiados, que acudían a la corte de Isabel Clara Eugenia, buscando refugio a causa de la persecución que padecían en sus respectivos reinos por defender la confesión católica. En primer lugar, los católicos franceses, que habían luchado (la "Liga de París") contra los hugonotes ${ }^{76}$, y que tras la conversión de Enrique IV, promovida y admitida por Clemente VIII, se sintieron traicionados en su fe y desesperados por los sufrimientos mantenidos en defensa de la Iglesia de Roma durante muchos años. Estos mismos combatientes habían defendido la posibilidad de que Isabel Clara Eugenia fuera una firme candidata al trono de Francia ${ }^{77}$. La frustración que produjo en ellos este fracaso, les llevó a transcender sus ideales materiales y radicarlos en vivencias espirituales, lo que produjo, al final del siglo XVI, que apareciesen diferentes corrientes místicas ${ }^{78}$. Este fue el caso del duque de Guisa, miembro influyente en la Liga Católica Francesa. El duque había huido a los Países Bajos en 1589 después de que

74 Raeymaekers (2013: 184).

75 Houben y Raeymaekers (2014: 123-145).

76 Descimon y Ruiz Ibañez (2005)

77 L'Epinois (1883: 34-114). Konigsberger (1955: 335-351). Baumgartner (1976). Martínez Millán y Carlos Morales (1998: 255-260).

78 Cognet (1966: 238-241). 
su poder se derrumbase, siendo declarado culpable de lesa majestad en ausencia. Se convirtió en pensionista del rey español y miembro célebre de la corte de Isabel. Como jefe del movimiento católico militante en Francia, el duque de Aumale fue una figura de gran valor propagandístico para el proyecto de los Archiduques de establecer la uniformidad religiosa en los Países Bajos. Stuart Carroll expresó el papel de la familia del duque en la lucha contra el protestantismo de la siguiente manera: «Desde la década de 1560 el Guise se convirtió en un símbolo de la lucha contra la herejía y un foco para las ansiedades de grandes sectores de la Francia católica» ${ }^{79}$. La esperanza del partido "devoto", continuador en cierto sentido de la Liga, fue siempre volver a la concepción unitaria de la Iglesia. Como afirma R. Descimon, la espiritualidad ahora podía desarrollarse en un nuevo contexto político. Las nuevas órdenes religiosas (algunas ya implantadas en Francia, otras en proceso de fundación como el Carmelo Descalzo o los oratorianos) luchaban contra la herejía, favorecidas especialmente por infantas y princesas ${ }^{80}$. Por otra parte, la cruzada contra el turco (impulsada por Clemente VIII) proporcionaba un proyecto con el que todos podían mostrarse de acuerdo ${ }^{81}$. Por último, el compromiso sobre el que se construía el catolicismo real implicaba un cambio de género religioso que debía girar hacia la corrección política y en el que los escritos de piedad reemplazaron a los trabajos de doctrina, cosa que permitía eludir las cuestiones conflictivas derivadas de la conversión de Enrique IV $^{82}$. Este es el caso de Bárbara Avrillot (1556-1618), quien había nacido dentro de una familia acomodada y educada en las clarisas de Longchamps. A los catorce años contrajo matrimonio con Pierre Acarie, maitre des comptes, también devoto como ella. Tuvieron seis hijos, que Bárbara educó con total entrega, más tarde ingresó como carmelita bajo el nombre de María de la Encarnación. Su gloria consistió en la introducción del Carmelo descalzo de santa Teresa de Jesús en Francia. Pero poco a poco, su casa se convirtió en un centro de espiritualidad, pero después compró una casa en el monte de santa Genoveva y se llevó los religiosos. En su círculo, se integraron personajes de gran relieve espiritual como Antonio Estienne, traductor de las Institutions de Tauler, los capuchinos, Benito de Canfeld, el jesuita P. Coton, el doctor de la Sorbona Andrés Duval (que escribió la biografía de

\footnotetext{
79 Carroll (1998: 105-106).

80 Diefendorf (1997: 177-179).

81 Michaud (2000: 457-472).

82 Descimon y Ruiz Ibáñez (2005 : 36-37)
} 
Mme Acarie), Quintanadoine, traductor al francés de las obras de santa Teresa, y el joven Pierre de Bérulle, primo de la mística ${ }^{83}$. Acarie recibió y apoyó a las discípulas de santa Teresa (Ana de San Bartolomé y Ana de Jesús) que fueron a implantar los conventos del Carmelo descalzo a Francia y, por consiguiente, mantuvo relación con Isabel clara Eugenia ${ }^{84}$. Las tendencias místicas que marcaron en Francia los últimos años del XVI, tuvo un buen representante de la escuela "abstracta" en Benito de Canfeld (1562-1610), capuchino de origen inglés, convertido del puritanismo, profesó como capuchino y llegó a ser uno de los grandes místicos de Francia ${ }^{85}$. Su pensamiento se encuentra resumido en su pequeña obra: Règle de perfection contenant un bref et lucide abrégé de toute la vie spirituelle réduite à ce seul point de la volonté de Dieu.

Además de los católicos franceses, otros refugiados, perseguidos por sus ideas religiosas y que experimentaron una transformación interior paralela, también influyeron en la radicalización espiritual de Isabel Clara Eugenia, tales como los irlandeses perseguidos: el católico Dermot O'Mallun, baron de O'Mallun, cuyas posesiones en Irlanda fueron confiscadas, se refugió en Bruselas y los Archiduques lo nombraron gentilhombre de la boca con sus rentas respectivas para poder vivir. Pero, sin duda, fueron los flamencos o neerlandeses perseguidos por los calvinistas de los Países Bajos quienes más influyeron en consolidar una espiritualidad radical, conectada con la ideología que Roma trataba de difundir ${ }^{86}$.

\section{2. El dilema de Isabel Clara Eugenia}

Durante el período en que Isabel Clara Eugenia estuvo de gobernadora de los Países Bajos comenzó a percibirse la divergencia que existía en su ánimo tanto en sus ideales religiosos como políticos. Ciertamente, como hija de Felipe II, sus preocupaciones políticas fundamentales eran mantener unidos todos los territorios que la conformaban, ahora bien, la Monarquía hispana estaba basada en una construcción ideológica y en

83 El trabajo de Bremond (1921, III) presenta a Bérulle completamente original, lo que es a todas luces falso. Posteriormente, cuatro obras han venido a realizar un estudio serio de su pensamiento y religiosidad: J. Dagens (1952); Cochois (1963); Dupuy (1964) y Orcibal (1872).

84

85 86

Optat de Veghel (1949, passim).

6 Wyhe (2005: 970-980). 
una tradición que no coincidía con el catolicismo de los Países Bajos y mucho menos con el que pretendía difundir la Iglesia católica (después de Trento), basada en una espiritualidad radical, fiel a Roma, al margen de las presiones políticas de las Monarquías europeas. Este conflicto, que Isabel pudo compaginar durante la etapa de infanta hispana, se hizo imposible de mantener cuando fue nombrada gobernadora de los Países Bajos ${ }^{87}$. La evolución del Carmelo descalzo, que la Infanta apoyó en su difusión, puede ayudar a entender esta contradicción en la práctica.

Una de las estructuras fundamentales para llevar a cabo el proceso de confesionalización, ejecutado por Felipe II, radicaba en la reforma de las Órdenes religiosas. Ciertamente, el concilio de Trento había legislado de manera clara sobre este tema, ahora bien, el rey quería que las reformas estuvieran en manos de los obispos con el fin de poder controlarlas el propio monarca ${ }^{88}$. Esta situación creó numerosos problemas de jurisdicción entre el papado y el monarca, toda vez que el rey invadía la jurisdicción eclesiástica en su afán de utilizar la religión en provecho de sus intereses políticos. Teresa de Jesús fue consciente de la situación política y religiosa de la Monarquía y de los intereses e ideología que movían a la elite de "letrados" castellanos que la gobernaban junto al rey. Asimismo, era consciente de su origen judeoconverso y de la reforma espiritual que pretendía desarrollar, ambas cosas contrarias a los patrones ideológicos y culturales de los que se estaba construyendo la nueva Monarquía de Felipe II. Si quería llevar a cabo su obra, era preciso realizarla de acuerdo con los

87 Se lo explicaba con claridad a su hermano Felipe III en una carta fechada en Bruselas el 15 de diciembre 1614: "Cuando no hubieran traido otra pesadumbre estas cosas de Juliers sino el habernos tenido con la pluma en la mano cada día aguardando poder escribir alguna buena conclusión y haber tardado tanto esto que nos ha hecho no escribir en tanto tiempo, bastaba para aborrecellas. Yo no sé cómo lo hubiera pasado con las cartas que he recibido de $V$. M., cierto yo no sé como poderla servir jamás a $V$. $M$. pero todo lo que puedo procuro cumplir con esta obligación y estoy cierta que nadie me lleva ventaja en procurarlo y en desear muchas ocasiones en que mostrar esta verdad. Lo mismo puedo asegurar a V. M. de mi primo y que, si no conociese lo que desea y procura servir a V. M., no le querría como le quiero. Esto suplico a $V$. M. que crea y más en esta ocasión para venir en lo que mi primo suplica a $V$. M., pues todos entendemos lo que conviene al servicio de V. M. y a su reputación» (AGS. E, leg. 8816. Isabel a Felipe III, Bruselas, 13 de diciembre fe 1614).

88 Los claustrales serían diseminados por los conventos de la observancia (breve Maxime cuperemus); de las monjas no se hablaba en el breve. Requesens advertía que «se descuidó el secretario del papa de ponello». Diez días después salía otro breve para ellas (Cum gravissimis de causis, 12 diciembre 1566) (AGS. E, leg. 902, núm. 64). 
principios políticos y religiosos de la facción gobernante, por consiguiente, se imponía — por una parte - ganarse a sus principales representantes y darles la seguridad que tanto su pensamiento como sus vivencias espirituales se hallaban dentro de la ortodoxia que ellos practicaban, evitando cualquier sospecha de herejía "alumbrada" y — por otra - de manifestar su completa integración en la sociedad cristiano vieja sin dar posibilidad a que le recordasen sus orígenes judeoconversos. Fue aquí donde Teresa de Jesús mostró, no solo ser una persona santa, sino también de poseer unas habilidades especiales para las relaciones sociales. No se puede explicar de otro modo que la cascada de fundaciones de conventos descalzos la llevase a cabo durante el período en que estuvo en el poder el partido "castellano" (bajo el patronazgo del cardenal Diego de Espinosa, 1565-1572), contrario al espíritu radical e interiorista que propugnaba la "descalcez" 89 . Para lograr su proyecto, Teresa de Jesús trató de establecer una relación estrecha con los principales miembros del grupo castellano, pero también buscó el apoyo y bendición del pontífice a través de sus nuncios en Madrid ${ }^{90}$. No obstante, con la llegada a Madrid del nuevo nuncio Felipe Sega, el 29 agosto 1577 , las cosas cambiaron y el enfrentamiento entre Madrid y Roma se hizo mucho más tenso. Según Roma, la reforma de los carmelitas iba a encomendarse a un comisario nombrado por el general ${ }^{91}$; de nada sirvieron las visitas que le hicieron (por encargo del rey) el cardenal Quiroga y otros letrados pertenecientes al "partido papista" y, por consiguiente, partidarios de los descalzos ${ }^{92}$. Ante postura tan rígida, el padre Gracián, que había sido destituido del cargo de visitador por el nuevo nuncio, comenzó a enviar memoriales al rey en los que acentuaba "los grandes inconvenientes que se seguían en los religiosos de España si los nuncios daban los breves contra las ordenaciones de sus superiores". Por su parte, la madre Teresa comprendió que si quería llevar a cabo su obra dentro de la Monarquía hispana debía ganarse la confianza del rey ${ }^{93}$. La intervención de Teresa de Jesús ante Felipe II tuvo sus frutos. El 22 de junio de 1580, Gregorio XIII, en su breve Pia consideratione, accedió a la petición del Rey Prudente y a los deseos de Teresa de Jesús. Ahora bien, el papado siempre tuvo presente

89 Martínez Millán y Visceglia (2007, I: «introducción»).

90 Martínez Millán (2015).

91 Cruz (1974: 365-422). Gattoni (2007); Fernández Collado (1991).

92 Martínez Millán y Carlos Morales (1998: cap. $6^{\circ}$ ).

93 Carta de santa Teresa a Felipe II, fechada en Sevilla el 19 de julio de 1575, Teresa de Jesús (1959, III, 134). 
que el Carmelo descalzo hispano (cuya espiritualidad estaba de acuerdo con los ideales de Roma) estaba bajo la sombra del monarca hispano por lo que era necesario por lo que era necesario reincorporarlo a la obediencia del pontífice. Este proceso fue realizado por Clemente VIII (1592-1604), quien tomó la drástica decisión de dividir la Orden carmelitana "descalza" en dos obediencias:

El acontecimiento más notable y acaso el de más trascendencia que ha conocido la Descalcez después de su cuna, fue la erección por Clemente VIII de la Congregación de San Elías de Italia, independientemente de la llamada Congregación de San José de España. Desde 1583 en que el P. Jerónimo Gracián envió al P. Nicolás Doria con facultades para fundar en Génova un convento de Descalzos, no se había hecho nada por extenderla, ni en Italia, ni en ninguna otra nación de Europa ${ }^{94}$.

En efecto, el Carmelo descalzo (de "obediencia hispana") intentó extender a otros territorios, fundando conventos en Génova, para lo que se valieron de la intervención que los banqueros genoveses tenían en la Monarquía española, prestándole dinero a la corona ${ }^{95}$. La fundación que hizo el padre Doria en Génova no fue bien recibida por el General de los carmelitas, el padre Caffardo, toda vez que el nuevo convento se instauró de acuerdo con las constituciones acordadas en el capítulo de Almodóvar de 26 de agosto $1576^{96}$.

Para fundar el convento de Génova, el padre Doria se llevó algunos descalzos españoles, el padre fray Pedro de la Madre de Dios y el hermano Juan de San Jerónimo ${ }^{97}$. Fray Pedro fue llamado a Roma para tratar

94 Silverio Santa Teresa, (1937, VIII, 1); Santa María (1644-1655)

95 Ruiz Martín (1968: 137-138). El «medio general» de 5 de diciembre de 1577. Para la creación del convento de descalzos en Génova por el padre Doria, Roggero (1984: 48-53).

96 Smet (1987, II: 125 ss). El capítulo de Almodóvar se reunió bajo la presidencia de Gracián. Se decidió, entre otras cosas, enviar dos frailes a Roma para negociar a favor de la reforma; prescindir de cierto número de frailes y nombrar provincial celoso. Gracián, por su propia iniciativa, separó la reforma de las provincias y se puso a su cabeza. El nuncio Sega declaró nulo este proceso el 16 de octubre; es más, colocó a los frailes descalzos y a las monjas bajo la jurisdicción de los provinciales de Castilla y Andalucía.

97 Nació en Daroca el 16 de agosto de 1565. Vistió el hábito en Pastrana. Estudió en Alcalá de Henares 
cuestiones relativas a las misiones de la Orden, mientras que el General prohibió al padre Doria acercarse a Roma y le ordena volver a España, pero cuando iniciaba el viaje llegaba a Génova el cardenal Alessandrini, que había sido nuncio en España, lo recogió y lo llevó por mar a la Ciudad Eterna en su compañía. En Roma, Alessandrini presentó al carmelita a Clemente VIII, quien permitió que se fundara un convento en el que se educase a los nuevos carmelitas descalzos dependientes de Roma. Así tuvo su origen la fundación Santa María de la Scala en el Trastévere. Al mismo tiempo, el 20 de marzo de 1597, el Pontífice extendía una serie de breves por los que eximía a los conventos de Génova y Roma de la jurisdicción de los Superiores hispanos, al mismo tiempo que los ponía bajo la inmediata dirección de la Santa Sede, les autoriza a tener novicios y a participar de los mismos privilegios y gracias que ya poseían los conventos españoles. Finalmente, Clemente VIII encargó al cardenal Pinelli que se hiciera cargo de los conventos de Roma y Génova y que estableciera las Constituciones ${ }^{98}$. El 13 de noviembre de 1600, el Pontífice ratificaba todas las gracias concedidas en los breves de 1597 y nombró a Pedro de la Madre de Dios, que era superior de la Scala, Comisario General de la Orden excepto de los conventos situados en los territorios de la Monarquía hispana.

La introducción de las carmelitas en Francia se debió al caballero Juan de Quintanadueñas de Bretigny, de padre español, pero nacido en Ruán. Quintanadueñas pasó su niñez en Sevilla, hasta los catorce años, que se marchó a Ruán. En 1582 tuvo que volver a Sevilla por motivos de negocios y, durante su estancia conoció al padre Gracián ${ }^{99}$. Quintanadueñas había participado en el establecimiento de las carmelitas en Lisboa se mostraba muy partidario de las misiones en las Indias occidentales. En su afán por establecer rápidamente las carmelitas en Francia, éste se trasladó a Pastrana, en octubre 1585, donde se acabó el Capítulo iniciado en

98 El duque de Sessa, embajador español en Roma, daba noticia al rey de estas decisiones tomadas por el Pontífice en carta, fechada el 5 de mayo (AGS. E, leg. 364).

99 Peregrinación de Anastasio, diálogo XIII (B. M. C., vol. 17, p. 207). «Trató conmigo por cartas a este tiempo que yo estaba en Roma cuan deseado era un convento de Carmelitas Descalzas en Roán y que había principios para fundare, porque el cardenal Joyosa les favorecía [...] y porque había muerto María de San José, priora de Lisboa, que ellos pedían, vino por fundadora Ana de Jesús con sus compañeras; y viniendo a París para alcanzar el beneplácito del Rey con que fundar en Roán, ayudado la duquesa de Longavilla y otras personas principales, se fundó el convento en París». Es preciso advertir que el cardenal Joyosa era enemigo de España en la corte del Papa. 
Lisboa, nombrando provincial de reforma al padre Nicolás Doria, quien acogió la propuesta, siempre que se cumplieran dos requisitos: obtener el consentimiento del rey (Felipe II) y que diesen principio las fundaciones de religiosos para que, cuando llegasen las monjas tuvieran quien las dirigieran ${ }^{100}$. El entusiasta benefactor no vio problemas en estas dos condiciones, por lo que se puso a trabajar para llevar a las monjas a su ciudad, pero el Consejo Real no aprobó el proyecto de Bretigny ${ }^{101}$, por lo que se negó a dar licencia, y volvió a Francia, en 1594, dedicándose a traducir las obras de Santa Teresa al francés. Las obras fueron leídas por Bárbara de Avrillot, mujer del contador real Acarie. Fue esta mujer quien movió a altos eclesiásticos franceses para llevar a cabo el proyecto que no había logrado instaurar Bretigny ${ }^{102}$. Con la ayuda de la princesa de Longueville y el concurso de Gallemant, Duval y Berulle, solicitaron a Enrique IV la fundación de un convento en París; esto es, el proyecto partía de Francia, si bien, fue preciso traer las monjas de España.

La elegida para implantar las carmelitas en Francia fue la madre Ana de Jesús, que se hallaba en Salamanca después de haber padecido la persecución del padre Doria ${ }^{103}$. Julen Urkiza explica, en un breve resumen, cómo doña Beatriz Zamudio, que acompañó a Isabel Clara Eugenia a Flandes, conocía a la carmelita descalza Ana de Jesús y sus aventuras en Francia, por lo que aconsejó a la infanta que la llamase para hacer fundaciones en Flandes ${ }^{104}$. En los intentos de la Infanta, recurrió a varios prelados eclesiásticos, siendo el intermediario Juan de Quintanadueñas Brétigny, quien había traducido los escritos de santa Teresa al francés ${ }^{105}$. En 1605 fundaba un convento en Pontoise; ahora bien, pronto encontró dificultades y problemas con Bérulle, superior del Carmelo francés, por diferencias de criterios. El clérigo francés defendía unas estructuras de la nueva orden de acuerdo con Roma, mientras la religiosa hispana, si bien estaba de acuerdo con la espiritualidad estrecha y formalista de Doria y demás carmelitas hispanos, era ferviente partidaria de la obra de Santa Teresa, quien la había podido llevar a cabo gracias al consentimiento del grupo "castellano" de

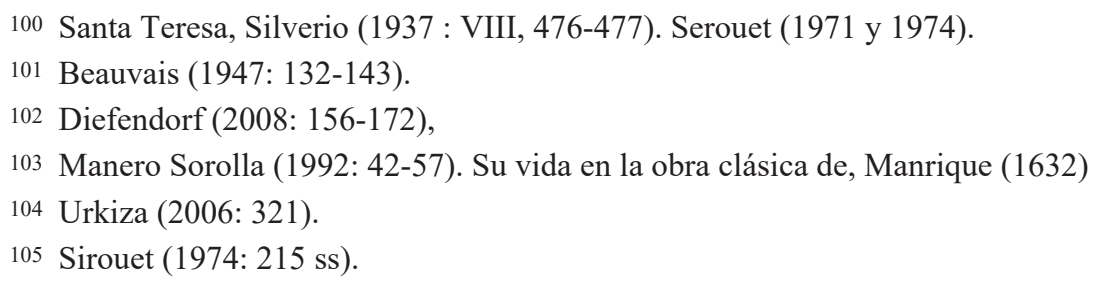


la corte de Felipe $\mathrm{II}^{106}$. Estas discrepancias se hicieron manifiestas en la fundación del convento de Dijon, en el que la madre Ana de Jesús quiso que los directores espirituales fueran padres carmelitas hispanos y Bérulle no lo consintió. A partir de entonces, la intención de la madre era volver cuanto antes a Castilla, dado que se había percatado de las limitaciones de su actuación en Francia ${ }^{107}$.

La infanta Isabel Clara Eugenia había asumido la devoción por la orden teresiana, llegando a ser uno de los miembros de la familia real que defendieron a los seguidores de la santa ${ }^{108}$; esto es, de la espiritualidad "descalza". El modelo que adoptó el convento de las carmelitas descalzas de Bruselas fue la misma que las "Descalzas reales" de Madrid"109. Dicho convento siempre fue un centro de espiritualidad radical y, durante los últimos años del reinado de Felipe II se constituyó en un centro de oposición política y religiosa a las instauradas por el Rey Prudente ${ }^{110}$. Ana de Jesús llegó a Bruselas en enero de 1607 y, en 25 de enero, tomaba posesión en presencia de los Archiduques de su monasterio provisional ${ }^{111}$. Este apoyo y entusiasmo permitió a que otra discípula de Teresa de Jesús, Ana de san Bartolomé saliera de París y se trasladara a Flandes, donde fundó el Carmelo de Amberes en 1612. Desde esta fecha hasta 1626, en que murió, fundó doce conventos. Mientras en España, los conventos carmelitas descalzos se extendieron durante el reinado de Felipe III de acuerdo a la obediencia de la provincia de San José, en las Monarquías europeas e, incluso, en los territorios vinculados indirectamente a la Monarquía hispana, la expansión carmelita descalza se produjo desde la obediencia dependiente de Roma.

Estas divergencias eran las que denunciaba Ana de Jesús al comprobar que tanto trabajo no daba los frutos esperados. La honesta monja, que no

106 Morgain (1995). Manero Sorolla (1991: 126-130). Houssaye (1872).

107 Bossche (1958: 203-208).

108 Green (1989: 29).

109 «También hay un monasterio en Borgoña, que fundó la madre Ana de Jesús, la cual está aquí en Bruselas a la fundación de otro que hace la Infanta [Isabel] con aquella suntuosidad y fábrica que el que hizo la Princesa [Juana] en Madrid y se entiende que lleva fin de enterrarse en él y, si quedase viuda, recogerse en un cuarto» (Carta de Jerónimo Gracián a su hermana, la hermana Juliana del convento de carmelitas de Sevilla, fechada en Bruselas el 8 de julio de 1608. Gracias de la Madre de Dios (1933, III: 402), editadas por P. Silverio de Santa Teresa.
110 Wyhe (2005: 466)
111 Urkiza (2006: 321). 
entendía de jurisdicciones sino de vivencias religiosas, se dio cuenta de la situación como escribía a fray Diego de Guevara:

Esta primavera tendremos aquí nuestros frailes descalzos de Roma, llamados de sus Altezas y deseados destas tierras. Antes que los pidiéramos de acá, los había mandado su Santidad viniesen a fundar aquí y a Francia. Viene por mayor, el padre fray Tomás de Jesús, con recados del Papa y del Padre Vicario General de nuestra orden. Darán la obediencia estos conventos. Nosotras jamás nos apartaremos de España y hemos escrito a nuestro padre General ordene lo que quiere que hagamos que, en dejando aquí gobierno de la orden, no podemos ir sin escrúpulo de que aflojara lo comenzado que está muy impreso en las que hemos recibido y en pocos años se fundará aquí ${ }^{12}$.

Poco tiempo después insistía en el mismo tema:

que ya hemos procurado lo que se os ha confesado de tener breve de Su Santidad para que los prelados de Italia no nos puedan estorbar el volver a España las que venimos cuando pareciere a cada una, ni los de allá a ir al convento donde profesamos. Por todas lo procuré antes de dar la obediencia. Dímosla en presencia del nuncio, después de que el padre fray Tomás de Jesús con cinco religiosos que trae consigo, había fundado su convento en esta ciudad ${ }^{113}$.

Las dificultades que atravesaban las carmelitas españolas eran cada vez más fuertes y Ana de Jesús era consciente de que su actividad en Flandes había finalizado:

[...] mas no se puede en este estado, aun nos limitan el dar limosnas. Muchas les han hecho aquí a nuestros Descalzos [se refiere a los de Italia] y en Francia bien los aceptan en estas tierras. Y harto querríamos fundaciones de nosotras, mas el nuevo General de Italia no sé cómo lo determinará, que comienza con tanta prudencia que le he escrito si no se ha de fundar más, no tenemos qué hacer acá ${ }^{114}$.

112 Carta fechada en Bruselas, el 15 de enero 1610, Torres (1996: 85).

113 Carta fechada en Bruselas el 21 de septiembre 1610, Torres (1996: 91).

114 Torres (1996: 95). 
El padre Jerónimo Gracián discrepaba de las ideas de Ana de Jesús como lo escribía a María de San José:

En lo que toca a nuestros negocios muchas cosas ha echado de ver la madre Ana en que se ha errado en estas fundaciones de aquí y, tratándolas conmigo, le digo las verdades, aunque sin instancia, no más que parecer seco. Las sus monjas prioras bien andan deseosas de seguir lo que les dijere, mas siempre ando huyendo de que no parezca que les aparto de su parecer de ella,

al mismo tiempo que se hacía eco de esta división jurisdiccional de las carmelitas descalzas: "De Roma he sabido que el Papa hace no sé qué congregación de Descalzos Carmelitas para dilatar la fe». En 1610, afirmaba que estaban esperando a «los Padres que vienen de Roma a gobernar a estas monjas». Todo ello se realizaba con el apoyo y beneplácito de Isabel Clara Eugenia que, como fiel hija de la Iglesia, obedecía al pontífice dejando al margen la obediencia del Carmelo hispano, que se mantenía bajo la sombra del monarca.

\section{Isabel Clara Eugenia, una Regente católica (1621-1633)}

Después de la muerte del Archiduque en 1621, los territorios del sur de los Países Bajos volvieron a la Corona hispana de acuerdo con el Acta de Cesión de 1598. No obstante, Isabel continuó en las Provincias desde Bruselas hasta su muerte, ocurrida en 1633, como gobernadora general ${ }^{115}$. Durante esta etapa, el contexto histórico cambió sustancialmente, lo que provoco que no solo tuviera que gobernar los Países Bajos de manera diferente, sino que además hiciera frente a los cambios que se habían producido en Europa. Hacía pocos años que se había iniciado la Guerra de los Treinta Años y la reanudación, ya en tiempos del Conde Duque de Olivares, afectó de manera especial a los Países Bajos; pero además, la propia justificación de Monarquía hispana, basada en la idea de Monarchia Universalis, se transformó en una nueva construcción político-religiosa conocida como Monarquía Católica, que subordinaba su ideología política a la predicada desde Roma. Para que sucediera tan profunda transformación, no solo tuvo que cambiar las estructuras de la Monarquía hispana, sino que también 
fue necesario que la Iglesia se configurase como autoridad independiente (Monarquía papal), sin la protección de los poderes temporales europeos, solo de esta manera conseguiría imponer su doctrina e iniciar autónomamente la expansión por el mundo, basándose exclusivamente en sus propios recursos para convencer a la gente: la predicación de las Órdenes religiosas y en la vida ejemplar de sus misioneros.

Tan profundos cambios, fueron producidos por la aparición de nuevas elites cortesanas distintas de las que habían dirigido la política en el siglo $\mathrm{XVI}$, que compartían y asimilaban las nuevas ideas religiosas y culturales. No cabe duda que este ambiente político y cultural facilitó que Isabel Clara Eugenia desarrollase más libremente sus ideas e inquietudes religiosas, que había ido desarrollando en su interior y que estaban muy en consonancia con la nueva situación. La Infanta asumió una espiritualidad, impuesta por Roma, que muy poco tenía que ver con la que ella había vivido en Castilla durante el siglo XVI. El comportamiento de Isabel Clara Eugenia se adaptó a la del "gobernante católico", cuyas características (al dictado de Roma) eran descritas por escritores tan representativos como el jesuita P. Nieremberg ${ }^{116}$. Para Nieremberg era necesario que un príncipe cristiano se mostrara temeroso de Dios, pero no sólo eso, exigía un cambio de actitud por parte del monarca y sus ministros con muestras de piedad y de devoción manifiestas.

\section{1. La imagen de una gobernadora católica}

En un excelente trabajo, fruto de su tesis doctoral, la profesora Cordula van Wyhe ${ }^{117}$ presentó las cualidades de la infanta Isabel Clara Eugenia identificándose con el paradigma católico del siglo XVII, que, sin duda, fue el que quiso establecer la Gobernadora de los Países Bajos. Esta imagen fue la de mujer virtuosa, reflejada en diferentes situaciones y actos cortesanos para que sirviera de ejemplo a la sociedad ${ }^{118}$. Es decir, Isabel Clara Eugenia impuso la virtud como estrategia política.

De acuerdo con la doctrina política del catolicismo romano del Barroco, las virtudes resultaban esenciales para un buen gobernante. Las virtudes

116 Nieremberg (1957: XVI-XVII)

117 Wyhe (2001). Le agradezco profundamente la generosidad y la confianza de enviarme su tesis doctoral en PDF para su lectura y utilización científica.

118 Kertzer (1988). Rebreviettes (1622). Klingenstein (1910: 24-34). 
morales eran conquistadas por el alma y la preparaba para actuar rectamente: en primer lugar, La virtud legitimaba la conducta del gobernante porque demostraba que su corazón recibía el apoyo de la divinidad a quien era responsable de sus actos. Dentro de la jerarquía estructurada de la sociedad, la comprensión de la conducta del monarca como arquetipo, estimulaba el deseo de identificarla con su persona pública ${ }^{119}$. Esta idea estaba justificada por escritores religiosos que utilizaban múltiples argumentos construidos por los padres de la Iglesia y generaciones de teólogos, basándose en la Biblia ${ }^{120}$. La representación de la Infanta como "gobernanta católica" asumía las mismas características (y se identificaba) que el "monarca católico" cuando el momento político lo requería; así, el cardinal Bentivoglio enfatizaba la imagen de Isabel Clara Eugenia como la de un guerrero heroico quien asumía el coraje de su marido (el archiduque Alberto) cuando describe para el pontífice la atención y auxilio prestado a los soldados en la batalla de Nieuwport ${ }^{121}$.

La humildad, por otro lado, es la cualidad espiritual que impulsa a los hombres a distanciarse o alienarse de sí mismos para poder reconocer y amar a Dios en los actos y oficios cotidianos de amor fraternal y subordinación voluntaria. La humildad se asocia con una comprensión del cuerpo físico como santificada por la adopción voluntaria de Cristo de la humilde condición de la humanidad diametralmente opuesta a la gloria y soberanía de su estado original y esencial como el Hijo de Dios ${ }^{122}$. Desde este punto de vista, la humildad estaba relacionada con la castidad. Esta percepción idealizada de lo sagrado de la virginidad y la castidad llevó a la creencia de que el honor, la belleza y la reputación de una mujer, en resumen, su autoridad secular y espiritual, descansaban en una condición: la perfección de la castidad ${ }^{123}$. La percepción de la mujer casta como inviolable e impermeable física y espiritualmente representaba una posibilidad de asociar a las mujeres, al menos en un nivel simbólico, con los atributos masculinos de valor, fuerza y fuerza. Mediante su adhesión a la castidad, la Infanta podría reclamar una forma viril de coraje que se relacionaba estrechamente con la virtud de la fortaleza, la firmeza del alma que permitía a los fieles

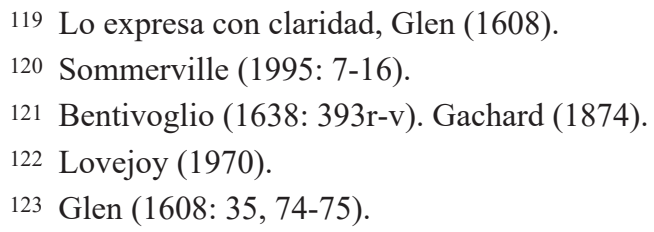


adherirse a un curso virtuoso de acción frente a la muerte o las tentaciones ${ }^{124}$. La imagen de Isabel durante el período de regencia siempre fue de una persona humilde, caritativa y casta, muy en consonancia con las enseñanzas de la época acerca de la obediencia de la mujer, que siempre se dio en los miembros de la corte española y de Bruselas.

Como imagen de Cristo, en opinión de Soto, el gobernante debía defender los principios femeninos de la humildad y la caridad, pero también la autoridad paterna. Según de Soto, estas eran las virtudes de las que sigue la obediencia y el amor: «... la paz es un efecto de la caridad». En consecuencia, el gobernante debía tratar a sus súbditos como a sus hijos: «Reyes y Príncipes deben amar y tratar como hijos a sus hijos y vasallos» ${ }^{125}$. Esta función de padre, que le atribuye Soto al gobernante, se traduce en la búsqueda de la paz, que el confesor exigía a la Infanta con el fin de conseguir la renovación de la Tregua de los doce años. En su dedicación a ella, se dirigía a Isabel como su verdadera hija espiritual presentándola como «Princesa de la Paz, Hija de la Christianissima Reyna Doña Isabel de la Paz». En otras palabras, a los ojos de de Soto, la Infanta debería convertirse en la madre humilde y caritativa de sus súbditos, que les otorga la paz $^{126}$.

La promoción de la humildad y la caridad de la Infanta también engendraron su papel como madre de los Países Bajos. La idea de la encarnación como la adopción de Dios de la carne humana dio lugar a metáforas de la capacidad de creación femenina perfectamente resumidas en la Virgen, que concibió y nutrió a la divinidad en virtud de su pureza sin igual. La humanidad de Cristo, su cuerpo carnal, se identificó con la mujer, de acuerdo con la valoración análoga al espíritu y la carne. Esta dicotomía de género se expresó en la Encarnación: Cristo le debe su espíritu a Dios y su cuerpo a María ${ }^{127}$. El 19 agosto 1619, Isabel escribía a su hermano:

Aquí envío a V. M. relación de toda nuestra jornada, que duró nueve días, que fueron más de invierno que de verano, y con tanta agua que era un diluvio y así ha hecho harto daño en los panes, que ha sido harta lástima porque había muchos años que no se habían visto tales. Con todo, puedo

\footnotetext{
124 Puteanus (1622).

125 Soto (1621, fol. 12r).

126 Wyhe (2001: cap. $\left.4^{\circ}\right)$

127 Wyhe (2001: cap. $2^{\circ}$ )
} 
decir que se hizo muy bien nuestra jornada y que ha sido una de las de más gusto que hemos hecho por ver lo mucho que toda la gente ha mostrado de vernos, que ha sido cosa extraña. Y en Dinan, con no ser nuestros vasallos, llegaban a tocar el coche como reliquias de manera que ni bastaba guardia ni nos dejaban entrar ni salir en é ${ }^{128}$.

La práctica de estas virtudes esenciales dio por resultado la construcción de una corte de Bruselas como teatro de virtudes ${ }^{129}$. Los papeles familiares y virtuosos de la Infanta se representaron principalmente, aunque no exclusivamente, en el escenario de la corte. Los confines del ámbito doméstico con sus relaciones íntimas entre maestros y sirvientes fueron percibidos por los primeros teóricos políticos modernos como un indicador de la salud del orden político más amplio. En un nivel práctico, esta idea de la familia como imagen especular de la política se basó en la interdependencia de la corte y la casa principesca: eran inseparables, porque la corte era el lugar donde residía y gobernaba el monarca. De acuerdo con ello, las damas de honor de la Infanta fueron las figuras centrales dentro de esta representación ritual de la imagen de la virtuosa familia archiducal. Ocuparon la posición de alto rango de los servidores de la cámara, que era un departamento doméstico dedicado a sus necesidades diarias y estructurado según una jerarquía definida basada en la proximidad a la Infanta.

La defensa de estas virtudes fue propiciada por una nueva facción que se manifestó en la defensa del monasterio de Laken ${ }^{130}$, liderada por Jacobus Boonen (1573-1655), Arzobispo de Malinas desde 1621. La carrera de Boonen fue fomentada y modelada por los Archiduques: el 24 de septiembre de 1611, lo nominaron consejero eclesiástico del Gran Consejo de Mechelen. En 1621, celebró su entrada feliz en Mechelen como arzobispo gracias a la intervención previa de los archiduques en su nombre. Los soberanos conjuntos habían heredado su derecho a elegir obispos y abades dentro de sus reinos desde los tiempos de Felipe II. Este privilegio era políticamente vital, porque aseguraba la obediencia de los obispos que estaban obligados a los Archiduques por su alta posición. La lealtad de Boonen a los Archiduques fue particularmente importante para la

128 AGS. E, leg. 8816, Marimont, 19 agosto 1619.

129 Lisola (1654: 634).

130 Sobre la importancia y significado del monasterio de Laken en este proceso ideológico, me remito, Wyhe (2001: cap. $2^{\circ}$ ). 
restauración y expansión de Laken. Porque, como Arzobispo de Malinas, fue el responsable directo del lugar de peregrinación, que había sido colocado en 1561 bajo la autoridad espiritual y política de la arquidiócesis de Malinas. Además, como Arzobispo, Boonen también era ex abad de oficio de Afflighem, el monasterio del cual Laken era una dependencia. La relación entre Jacobus Boonen y la viuda Infanta parece haber sido una simbiosis basada en intereses complementarios: mientras que la expansión de Laken por Isabel durante su viudez aumentó el prestigio de Boonen como seigneur espiritual del sitio, la Infanta podía confiar en el Arzobispo como consejero leal y obediente partidario de sus proyectos.

El nombramiento de Jacobus Boonen como arzobispo de Malinas lo convirtió en uno de los eclesiásticos más importantes de los Países Bajos entre 1621 y 1650. Su nombramiento implicó un cambio de facciones en la corte. Como feroz anti-jesuita promovió a los proto-jansenistas a expensas de la Compañía de Jesús ${ }^{131}$. Cornelio Otto Jansenius (1585-1638), el fundador de este movimiento espiritual, defendió la idea agustiniana de la gratuidad absoluta de la predestinación y la eficacia de la gracia. Esta visión rígida de la naturaleza humana como restringida a un círculo de elegidos entraba en conflicto con la enseñanza más optimista de la gracia de los jesuitas, que dependía de la previsión de los méritos. Los principales partidarios de las interpretaciones de San Agustín de Jansenius fueron los dominicanos y los oratorianos franceses. Después de que los intentos de Aumale de instituir un convento Minim en Laken parecieran haber fallado, Boonen persuadió a la Infanta a fundar un Oratorio siguiendo el patrón establecido por Pierre de Bérulle y en 1626 un vicario, un sacerdote, dos capellanes y un acólito llegaron de Francia. De nuevo, la Archiduquesa estaba dispuesta a pagar una suma considerable, 1000 florines, por la creación de este servicio clerical. El servicio clerical anterior en Laken había caído en declive después de que los sacerdotes se marcharan debido a salarios insuficientes. El monasterio de Afflighem había sido saqueado tres veces durante las revueltas (dos veces por iconoclastas, una vez por amotinados españoles) y una reconstrucción comenzó en 1605, un tiempo después de que Laken fuera re-consagrada. Por lo tanto, no es sorprendente que el monasterio no haya podido proporcionar una vida digna a los sacerdotes de Laken. La presentación de Boonen de los Oratorianos franceses en Laken fue solo una parte de su apoyo más amplio a esta orden; una

131 Wyhe (2001: cap. $\left.2^{\circ}\right)$. 
predilección que Boonen compartía con ciertos jansenistas a los que estaba estrechamente afiliado. Boonen continuó apoyando activamente los cultos que de Soto ya había fomentado quince años antes ${ }^{132}$.

\subsection{EI apoyo de Isabel Clara Eugenia a Roma}

No cabe duda de que la asimilación del catolicismo político por parte de Isabel Clara Eugenia, llevó consigo el apoyo material a la Santa Sede. En este sentido Isabel adoptó unas decisiones favorables a los intereses y a la consolidación institucional de la Iglesia que los pontífices de principios del siglo XVII estaban acometiendo y que, en cierto sentido, no eran favorables para los intereses materiales de la Monarquía hispana. No solo se estableció de manera perenne una nunciatura en Bruselas ya en 1596, tras el nombramiento del archiduque Ernesto como gobernador general $(1594)^{133}$, sino que Roma aconsejaba a sus nuncios que mantuvieran unas relaciones excelentes con los Archiduques por la importancia que el papado concedía a esta zona de Europa ${ }^{134}$. La cantidad de correspondencia que existe en los archivos vaticanos entre el nuncio de Bruselas o el de París con Roma sobrepasa en mucho a la que mantuvo la Santa Sede con Madrid a partir del reinado de Felipe III. Así mismo, el nuncio recibía advertencias por parte del pontífice de las buenas relaciones que debía mantener con el confesor de Isabel Clara Eugenia ${ }^{135}$. Guidi de Bagno no coincidía con Isabel Clara Eugenia (en cuanto gobernadora del monarca hispano) en la política que se debía seguir en los Países Bajos, pero realmente eran buenos amigos, coincidían en su concepto del catolicismo y en su espiritualidad ${ }^{136}$. René Vermier explica los enfrentamientos de la Infanta y Bagno en temas tan importantes como admitir la paz y la tregua en los Países Bajos o la cuestión suscitada en el Palatinado con Federico $\mathrm{V}$, sin embargo, a pesar de las posturas enfrentadas por las diferentes conveniencias política de Roma y Madrid, «el nuncio dejó claro a Roma que sus ruegos para que la infanta no tuviese en cuenta las amenazas de Jacobo I no habían caído en saco roto» ${ }^{137}$. Además, señalaba que Isabel ofreció

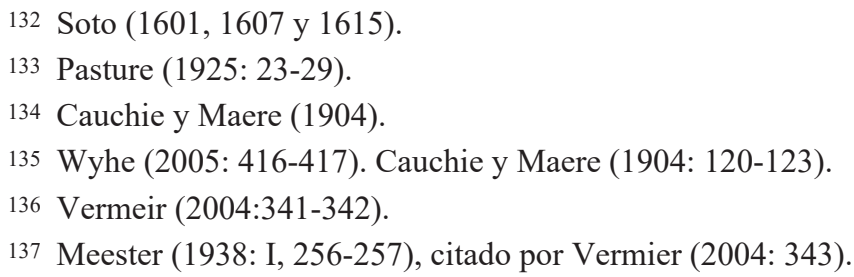


gran apoyo para que se canonizasen a santa Teresa de Jesús, Ignacio de Loyola, Felipe Neri y Francisco Javier, todos santos de la nueva mentalidad de la Iglesia.

Pero, sin duda, donde más se manifestó la concordancia existente de Isabel Clara Eugenia con los proyectos de Roma fue en el apoyo y colaboración que ofreció en la creación de la Congregación Propaganda Fide. La fundación de la Congregación de la Propaganda Fide no se formó de la nada, sino que surgió tras un largo período de gestación que arranca de los últimos años del reinado de Felipe II $^{138}$. Ya en 1599, el pontífice instituyó, bajo el impulso del cardenal Santori, un colegio de cardenales responsables de las misiones en el mundo. Este grupo llevó el mismo nombre que la organización creada por Gregorio XV veinte años después ${ }^{139}$.

En la creación de Propaganda fide destaca de manera especial la labor de Juan Bautista Vives, que desde la corte de Bruselas estableció estrechos vínculos entre la corte flamenca y los cardenales de Propaganda Fide. Monseñor Vives, fue un clérigo valenciano (1545-1632) que trabajó como agente diplomático de la infanta Isabel Clara Eugenia en Roma. Fue el fundador del Colegio de Propaganda Fide en Roma, donde estudiaban los misioneros que debían después extender el catolicismo romano por el mundo. No he hallado abundantes referencias de su labor en Bruselas junto a la infanta Isabel Clara Eugenia; pero fue precisamente en la década de 1620 cuando las cartas que envió a los cardenales de Propaganda Fide testimonian que estaba junto a la Infanta. Desde Bruselas, antes de viajar a Roma, se empeñó en dar origen al Colegio de Propaganda Fide favoreciendo la creación de la primera sede oficial de la institución recién fundada. A partir de entonces, los cardenales tuvieron un lugar de reunión que sirvió también para formar a los misioneros. Desde marzo de 1624, la correspondencia de Vives con Propaganda Fide fue continua. No sólo se interesó por un lugar para la sede, comprando el céntrico Palacio Ferratini en la Piazza della Trinità, sino que además quiso beneficiar económicamente al colegio para que entrara un número sustancioso de futuros misioneros para formarlos. Para dotar económicamente al colegio, Vives escribió a Madrid para que, con el consentimiento de Felipe IV, pudiera donar los beneficios económicos de la Abadía que tenía en Calabria, que era de Patronato Regio, y otros 
beneficios eclesiásticos que dicho eclesiástico poseía ${ }^{140}$. El 3 de febrero de 1628, la colaboración de Monseñor Vives - con el respaldo de la infanta Isabel Clara Eugenia - con Propaganda Fide llegó a su punto más álgido, cuando Vives propuso la manera de conseguir más dinero para financiar la actividad apostólica del dicasterio. La propuesta trataba de recaudar dinero aplicando la décima en todas las donaciones, legados, testamentos y últimas voluntades que iría destinado a las misiones de la Congregación ${ }^{141}$.

En cuanto a la colaboración directa de la infanta Isabel Clara Eugenia con Propaganda Fide es preciso analizar algunos ejemplos más, para entender hasta qué punto fue promotora de la Congregación, y la importancia de esta mujer que desde Bruselas actuó como intermediaria entre las cortes de Madrid y Roma. Por estos años, la influencia y la desconfianza del conde duque de Olivares en la Congregación, convierte a la corte de Flandes en un lugar de mediación entre Propaganda Fide y la Monarquía Hispana. Misioneros de América llegaban a la corte de Bruselas — pero no a la de Madrid como correspondería - pidiendo a la infanta que les patrocinara ante la Congregación de Propaganda Fide para conseguir que mandasen más misioneros al Nuevo Mundo. Es el caso del misionero portugués Domenico Coelho, provincial de la Compañía de Jesús en Brasil que acudió a Bruselas para que la infanta Isabel pidiera más ayuda para sus misiones a Propaganda Fide, lo que evidencia la influencia de esta mujer sobre el dicasterio cardenalicio ${ }^{142}$.

140 «Monsignore Vives non solamente vuol dare al collegio erigendo la casa c'ha comprato per la sua habitatione, ma ancora lo vul dotare, perche li collegiati si possino mantenere fin a un buon numero, et non contento di darli tutta la sua robba temporale che possede, et aquistara mentre viva, disegna ancora darli entrata ecclesiastica, et fin adesso ha fatto diligenze in Spagna, per haver il consenso di sua Maestà per unirci un Abbatia che tienen in Calabria di patronato Reggio. Ancora vuol gravare, per tempo di 20 anni di pensione, alcuni beneficii ecclesiastici che possede». Roma, 26 de marzo de 1624, APF (Archivio Propaganda Fide), SOCG (Scritture Originali Riferite nelle Congrrgazioni Generali) 384, Memoriali del 1624 ed ultimi sei mesi del 1623: 238r.

141 APF, SOCG 388, Memoriali anno 1628, f. 32r.

142 «Venido dal Brassil il P. Domenico Coelho provincial della compagnia di Giesù del Brasil, per alcuni gratie, lui domanderà a V. Santità per servitio e consolatione di quei cattolici di qual Regno cosi lontano, supplica che sia ben visto, e spedito con sua sodisfattione attestado che'l detto padre è persona di valor, e di merito, e che in tutti li cariche della religione s'è portato bene». Carta de la infanta Isabel desde Bruselas a Propaganda, 10 de enero de 1627. APF, SOCG 129, Lettere di Francia, Fiandra, Spagna, Indie, Inghilterra ed Ibernia 1627, vol. IV: f. 35r. 


\section{3. La casa de Isabel Clara Eugenia}

Tras la muerte del archiduque Alberto, en 1621, la radicalidad de la vida religiosa de Isabel Clara Eugenia se intensificó llegando, incluso, a desprenderse de sus joyas, cortarse el pelo y vestir el hábito de terciaria ${ }^{143}$. Ella fijó su modelo de santidad en santa Isabel de Hungría (1207-1231), quien también tomó el hábito de san Francisco cuando murió su marido, Luis IV de Turingia ${ }^{144}$. En 1630, Jean Jacques Chiflet, médico de Isabel, escribía a Roma que la Infanta había prohibido entrar a ningún hombre en sus aposentos, ni siquiera los escasos oficios que podían hacerlo (mayordomo mayor, médicos de cámara y guardadamas, cargo ocupado por Jean de Monfort entre 1621 y 1633$)^{145}$. De esta manera, las mujeres que le servían, la camarera mayor y las damas de la cámara ejercieron una influencia indudable. Las dueñas de honor estaban compuestas por un conjunto de mujeres pertenecientes a la nobleza; se prefería que fueran de cierta edad porque sus obligaciones, comportamiento y figura requerían autoridad y respeto. Tales cargos eran muy apropiados para viudas. En este período, todas las mujeres tenían esas características: la camarera mayor, Antoinette Guillemette de Arenberg obtuvo el cargo en 1615, cuando llevaba cinco años viuda del conde de Salentin de Isenburg. Madame de Pallant fue nombrada dueña de honor en 1613, parece que también era viuda. Marie de Montmorency era una de las más amigas de Isabel, llegó a ser dama en 1610 y ascendió a dueña en 1622; antes de llegar a la corte, había estado en un convento de Mons. María Zapata (condesa de Villerval) y su hermana pasaron a ser damas de Isabel Clara Eugenia en 1610. Margarita de Borgoña entró como dama muy joven, pues había nacido en 1603, y fue nombrada en 1616; casó con el mayordomo mayor de Isabel, Hugues de Noailles, y conservó su oficio durante toda la vida de Isabel ${ }^{146}$.

Según B. Houben, la corte de Isabel siguió siendo la misma que cuando vivía su marido, si bien, la cámara del Archiduque desapareció, mientras adquirió gran importancia la cámara de las damas (Chambres des Dames) $)^{147}$. La misma historiadora señala que la totalidad de las damas y dueñas de honor, que componían la cámara, eran mujeres de edad y —en su gran

143 Wyhe (2004: 418-420). Sánchez (1998: 93-98)

144 Whyhe (2004: 419-420).

145 Houben, (2011: 316-317).

146 Los datos están tomados de Houben, (2011: 317-320).

147 Houben (2004: 314-315). 
mayoría - viudas con el fin de dar seriedad al servicio. Entre tales mujeres se encontraban Antonia Wilhelmina d'Arenberg (camarera mayor desde 1615), Antoinette de Ravanel (servía a Isabel desde 1605), Madame de Pallant (ingresó al servicio de la Infanta en 1613), Marie de Montmorency y María Zapata también sirvieron durante muchos años ${ }^{148}$.

Antoinette Guillemette de Arenberg fue un personaje influyente merced a su familia: su hermano Carlos d'Arenberg estuvo apoyado por los Archiduques y por la corte de Madrid, por lo que era un personaje muy relevante en Bruselas; así mismo, su matrimonio con Anne de Croÿ (duquesa de Aarschot), le sirvió para insertarse en la elite más selecta de Países Bajos. Gracias a sus presiones, su hermana Antoinette Guillemette fue nombrada camarera mayor. Esta, a su vez, consiguió colocar a las dos hijas de su nieto (Felipe d'Arenberg, duque de Aarschot) en la cámara de Isabel. No fue la única merced que obtuvo para su familia: consiguió el matrimonio de su hijo Ernesto, con la hija de su difunto hermano, Caroline d'Arenberg ${ }^{149}$.

Tras la muerte de Wilhelmina d'Arenberg, el cargo de camarera fue asumido por Antoniette Ravanel, condesa de Vere, quien llegó a tener una relación muy estrecha con Isabel, recomendándola en diversas ocasiones a la corte de Madrid hasta el punto de confesarle al duque de Lerma "no sabría qué hacer sin ella"150. Las dueñas que más influencia tuvieron en Isabel fueron María de Montmorency y la condesa de Villerval. Cuando el médico personal de Isabel Clara Eugenia pretendía obtener alguna merced recurría a ellas para que se la trasmitieran a la Gobernadora. En la última etapa de la vida de Isabel, sus damas de confianza (Montmorency y Villerval) adquirieron gran influencia con crítica de la corte y de la priori de las carmelitas descalzas de Gante. Aunque se puede achacar a la vejez y falta de fuerza de la Gobernadora, más bien pienso en la radicalidad de su espiritualidad.

Parece ser que, entre las dueñas, las que tuvieron mayor intimidad con Isabel Clara Eugenia fueron Marie de Montmorency y la condesa de Villerval a juzgar por las mercedes que alcanzaban para amigos y parientes de la gobernadora general. Esta influencia de las damas de cámara se fue

148 Houben (2004: 319-321).

149 Houben (2004: 320). Villermont (1912, II : 460-471).

150 Villermont (1912, II: 470-471). Carta de Isabel a Iñigo de Brizuela, citado por Houben (2004: 334, nota 54) 
haciendo más acuciante en los últimos años de vida de Isabel, cuando se encontraba enferma y desvalida.

Brigit Houben hace un recuento preciso de todas las familias que dominaron la corte y la casa de Isabel. Para ella existieron cinco familias borgoñonas que supieron extender sus raíces y juntar a la nobleza en una elite común: la familia Andelot: Fernando le Blanc d'Andelot entró en la corte de Alberto en 1608 y después de la muerte del Archiduque se quedó al servicio de Isabel, para ello alegó los servicios de sus antepasado, su padre, Juan Bautista, había servido como gentilhombe de la casa de Felipe II y su abuelo había sido caballerizo mayor de Carlos V. Uno de los hijos (Nicolás Antonio) de Fernando fue capellán del oratorio del Archiduque. Un tío suyo, Jorge d'Andelot, había sido Kämmerer del Emperador y otro tía, Gaspar, casó con Antonieta Rye, mientras que una hija de Fernando, Bárbara, casó con Alejandro, barón de Wiltz ${ }^{151}$. Felipe de Rye, conde de Varax, y Claudia de Tournon tuvieron seis hijos. El segundo, Francisco de Rye, llegó a ser sumiller de cortina de los Archiduques y en 1606 fue nombrado su limosnero mayor. Su hermano, Claudio, barón de Balançon, fue nombrado gentilhombre de la cámara del cardenal infante Fernando en 1635. Su hermana Eleonor fue dama de Isabel Clara Eugenia. Otra hermana, Ana Margarita Rye también fue dama en la cámara de la gobernadora y casó con Guillermo de Richardot, barón de Lembeck y más tarde conde de Galmaarden ${ }^{152}$.

Eugenio Leopoldo Perrenot de Granvella-d'Oiselay fue margrave del Sacro Imperio Romano y conde de Cantecroix, había entrado como menino de Isabel Clara Eugenia en 1630. El llegó a ser chamberlán consejero de Estado y favorito del emperador Fernando II. Era hijo de Francisco Tomás d'Oiselay, quien heredó la fortuna y los títulos de su tío Francisco Perrenot de Granvella, nieto del famoso Nicolás Perrenot. Francisco Tomás era un caballero de la Flecha Dorada, gentilhombre de cámara del archiduque Alberto y embajador ante Rodolfo II. Rodolfo, hermano de Alberto, engrandeció a Francisco Tomás con los títulos de margrave del Sacro Imperio Romano y nombrándolo conde de Cantecroix. Su hijo Eugenio Leopoldo casó en Bruselas con la hija mayor del barón de Belvoir, Beatriz de Cusance ${ }^{153}$.

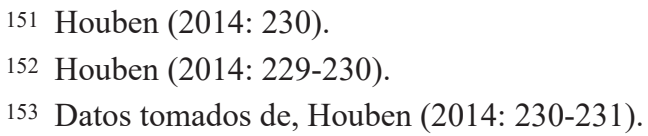


Por su parte, la familia Chifflet también había conseguido establecerse en al corte de los Archiduques formando un núcleo de redes de ciudades. Los hermanos Felipe y Jean Jacques Chifflet, capellán de oratorio y médico de Isabel y Alberto respectivamente. El padre, Juan Chifflet, lord de Palente, era médico de la ciudad de Besançon y miembro del consejo de la ciudad. Su esposa, Margarita Pouthier era hermana de un profesor de la universidad de Dole, capital del Franco Condado. Por su parte, Jean Jacques casó con Juana Bautista de Maubouhans con la que tuvo doce hijos, ocho de ellos sobrevivieron a la niñez; tres de ellos hicieron carrera en la corte, y uno de ellos, Julio llegó a Madrid en 1648, alcanzando el cargo de capellán de oratorio de Felipe IV ${ }^{154}$.

Reflexionando sobre las redes cortesanas que se establecieron durante la regencia de Isabel Clara Eugenia, se observa que se había formado una elite cortesana distinta de los personajes del siglo XVII (y que gozan de la confianza de la Gobernadora), pero es más, al final de la vida de la Infanta, se observa también que comenzaron a introducirse una nueva elite, como los Chifflet, que reflejaban una imagen social distinta a la tradicional; eran católicos cuyo comportamiento nos trasladan a las actuaciones de los miembros de la "República de las Letras"155.

\section{BIBLIOGRAFÍA}

Allen, Paul C, Felipe III y la pax hispanica, 1598-1621: el fracaso de la gran estrategia, Madrid, Alianza 2001.

Badura, B., «La casa de Dietrichstein y España», Ibero-americana pragensia 33 (1999), pp. 47-67.

Baumgartner, F. J., Radical Reactionaries: the Political Thought of the French Catholic League, Ginebra, Droz, 1976.

Beauvais, F. de, La vie de m. Brétigny, preste fundateur des carmélites de sainte Thérèse en France et aux pays bas, Paris, 1947.

Bentivoglio, G., Relaciones del cardenal Bentivoglio, traducido por Francisco de Mendoza y Céspedes, Madrid, 1638.

154 Para más datos, Houben (2014: 231).

155 Fumaroli (2013: 44-65). Bots y Waquet (2005: 11-14). Ferreti (2010: 109-110). 
Bonafont, «Les projets d'érection des pays bas en royaume du XVe au XVIIIe siècles». Revue de l'université de Bruxelles 41 (1935-36), pp.158-162.

Bossche, 1. van, Anne de Jésus, coadjutrice de sainte Thérèse d'Ávila, Brujas, 1958.

Bots, H. y Waquet, F., La reppublica delle lettere. Bolonia. Il mulino 2005.

Bremond, H. de, «L'ecole française», L'histoire littéraire du sentiment religieux, Paris 1921, vol. III.

Cabrera de Córdoba, Luis, Historia de Felipe II, rey de España, edición de J. Martínez Millán y C. J. Carlos Morales, Junta de Castilla y León 1998, 3 vols.

Carroll, S., Noble power during the wars of religion, the guise affinity and the catholic cause in normandy, Cambridge, 1998.

Carter, C. H., «Belgian "autonomy” under the Archdukes, 1598-1621», Journal of Modern History 36 (1964), pp. 245-259.

Cauchie, A. y Maere, R., Recueil des instructions générales aux nonces de flandes (1596-1635), Bruselas, 1904.

Cochois, P., Bérulle et l'ecole francaise, Seuil, París, Cerf, 1963.

Cognet, L., La spiritualité moderne. I.- l'essor: 1500-1650, París, 1966.

Cruz, J. de la, «Gracián y Sega frente a frente», Monte Carmelo, 72 (1974).

Cruz Medina, V. de la, «La educación de las meninas en la corte de Felipe II: algunos aspectos a través de las cartas de Ana de Dietrichstein a su madre, Margarita de Cardona», en Jiménez Eguizabal et alii (eds.), Etnohistoria de la escuela. XII coloquio nacional de historia de la educación, Burgos, 2003, pp. 523-534.

Cruz Medina, V. de la, «Manos que escriben cartas. Ana de Dietrichstein y el género epistolar en el siglo XVI», Litterae. Cuadernos sobre cultura escrita, III-IV (2003-2004), pp. 161-185.

Dagens, J., Bérulle et les origines de la restauration catholique (1575-1611), Paris, Desclée de Brouwer, 1952.

Descimon, Robert y Ruiz Ibáñez, J. Javier, Les ligueurs de l'exil. Le refuge catholique français après 1594, Seyssel, Champ Vallon, 2005.

Diagre, D., «L'archiduc Albert, souverain-modèle ou ange exterminateur?», en A. Morelli (ed.), Les grands mythes de l'histoire de belgique, de flandre et de wallonie, Brussels, 1995, pp. 117-128.

Diefendorf, B., "An age of gold? Parisian women, the Holy League, and of the Roots of Catholic Renewal», en M. Wolfe (ed), Changing Identities in Early Modern France, Durham, Duke University Press, 1997, pp.169-190.

Diefendorf, B., «Barbe Acarie and her Spiritual Daughers: Women’s Spiritual Authority in Seventeenth Century France!», en C. van Wyhe (ed.), Female Monasticim in Early Modern Europe. An Interdisiciplinary Vie, Alderhost, Ashgate, 2008, pp. 155-171. 
Duerloo, Luc, Archiduque Alberto. Piedad y política dinástica durante las guerras de religión, Madrid, CEEH, 2012.

Dupuy, M., Le cardinal de Bérulle : évolution d'une spiritualité, París, 1964.

Edelmayer, Frederic, «Honor y dinero. Adam de Dietrichstein al servicio de la casa de Austria», Studia histórica: Historia moderna, 11 (1993), pp. 89-116, accesible en líena: <http:/revistas.usal.es/index.php/Studia_Historica/article/view/4692/4708>.

Esteban Estríngana, Alicia, Guerra y finanzas en los países bajos católicos. De Farnesio a Spínola, 1592-1630, Madrid, Ediciones del Laberinto, 2002.

Fernández Collado, Ángel, Gregorio XIII y Felipe II en la nunciatura de Felipe Sega (1577-1581): aspectos politico, jurisdiccional y de reforma, Toledo, Estudio teológico de San Ildefonso, 1991.

Ferretti, G., «Les stratégies d'opposition dans l'académie Dupuy», A. Lefebvre (dir.), Comparaisons, raisons, raisons d'etat. Politiques de la république des lettres au tournant du XVIIe siécle, München, Oldenbourg, 2010, pp. 109-110.

Fumaroli, Marc, Nicolas claude fabri de peirese, prince de la république des lettres, traducción de J.R. Monreal, La república de las letras, Barcelona, Acantilado, 2013.

Gachard, Louis-Prosper, Le cardinal Bentivoglio. Sa nunciature à Bruxelles (16071615), Bruselas, 1874.

Gálvez de Montalvo, Luis, El pastor de Fílida, edición de M. A. Martínez San Juan, Universidad de Málaga, 2006.

García Prieto, Elisa, «Isabel Clara Eugenia de Austria: negociaciones matrimoniales y proyectos dinásticos para una infanta española», en C. van Wyhe (dir.), Isabel Clara Eugenia. Soberanía femenina en las cortes de Madrid y Bruselas, Madrid, CEEH, 2009.

Gattoni, M., Gregorio XIII e la política ibérica dello stato pontificio (1572-1585), Roma, Edizioni Studium, 2007.

Glen, J. B. de, Oeconomie chrestienne contenant les reigles de bien vivre, tant pour les gens mariés qu'à marier, pour nourrir et esleuer les enfans, fils, filles en la vraye pieté. ses serviteurs aussi et serva[n] te : compris en huict livres, Liege, 1608.

González Amezúa y Mayo, Agustín, Isabel de Valois, reina de España, Madrid, Gráficas Ultra, 1949, 3 vols.

Gracián de la Madre de Dios, Jerónimo, Obras. Burgos. Monte Carmelo 1933, 3 vols (edición de Silverio de Santa Teresa). Peregrinación de Anastasio, diálogo XIII (B. M. C., vol. 17).

Green, D., Gold in the Crucible. Teresa of Ávila and the Western Mystical Tradition, Shatesbury, Dorset, 1989.

Guzmán, Diego, Reina católica. vida y muerte de doña Margarita de Austria, reina de españa, Madrid, 1617. 
Hortal Muñoz, José Eloy, «The Household of Archduke Albert of Austria from his Election as Governor of the Habsburgo Netherlans until his Investidure as Sovereign Prince of the Low Countries (1595-1598)», Revue belge e philology et d'histoire 91 (2013), pp. 1011-1056.

Hortal Muñoz, José Eloy y Félix Labrador Arroyo, (dirs.), La Casa de Borgoña: la Casa del Rey de España, Leuven, University Press, 2014.

Houben, B., «Intimidad y política: Isabel y sus damas de honor (1621-1633)», en C. van Wyhe (coord.), Isabel Clara Eugenia. Soberanía femenina en las cortes de Madrid y Bruselas, Madrid, CEEH, 2004, pp. 312-336.

Houben, B. y D. Raeymaekers, «Women and the Politics of Access at the Count of Brussels. The infanta Isabelle's camareras mayores (1598-1633)», en, N. Akkerman and B. Houben (eds.), The Politics of Female Household: Ladies-inwaiting across Early Modern Europe, Leiden, Brill, 2014, pp. 123-145.

Houben, B., «Vous estez les premiers vassaux que j'aye et que j'aime le plus. Burgundians in the Brussels courts of the windowed Isabella and of the cardinal infant don Ferdinand (1621-1641)», en, R. Vermeir, D. Raeymarkers y J. E. Hortal Muñoz (eds.), A Constellation of Courts. The Courts and Households of Habsburgo Europe, 1555-1665, Leuven, University Press, 2014, pp. 223-254.

Houssaye, M. de, Bérulle et les carmélites de France, Paris, 1872.

Howard Green, O., Vida y obras de Lupercio Leonardo de Argensola, Zaragoza, Institución Fernando el Católico, 1945.

Israel, J. I., «The Court of Albert and Isabella, 1598-1621», Conflit of empires: Spain the Low Countries and the Struggle for World Supremacy, 1585-1713, London, Hambledon Press, 1997.

Jonge, Krista de, «Building Policy und Urbanization during the Reign of Archidukes: the Court and its Architets», en Thomas y Duerloo (eds.), Albert and Isabella, 1598-162. Essay, Turnhout, Brepols, 1998, pp. 191-219.

Jesús María (Quiroga), J. de, Historia general de la reforma del Carmen descalzo, Madrid, 1637.

Kertzer, D. I., Ritual, politics and power, New Haven/Conn, 1988.

Klingenstein, L., The great infanta Isabel, sovereign of the Netherlands, London, Methuen, 1910.

Konigsberger, Helmut, «The Organization of Revolutionary Parties in France and the Netherlands during the Sixteenth Century», Journal of Modern History 27 (1955), pp. 335- 351.

L’Epinois, H., «Les deniers jours de la ligue. La france de 1592. etats 1593, absolution d'Henri IV», Revue des question historiques 34 (1883), pp. 34-114.

Lefèvre, J., «Les ambassadeurs d'Espagne à Bruxelles sous le régne de l'archiduc Albert (11598-1621)», Revue belge de philologie et d'histoire 2 (1923), pp. 61-80. 
Lehfeldt, E. A. «Discipline, Vocation, and Patronage: Spanish Religious Women in a Tridentine Microclimate», Sixteenth Century Journal 30 (1999), pp. 1009-1030.

Lisola, F., Discours funebre sur la mort de la serenissime princesse isabelle clere Eugenie, infante d'Espagne, etc, Besançon, 1634.

Lonchay, H., «Philippe II et le mariage des archiducs Albert et Isabelle», Bulletin de la classe des lettres et des sciences morales et politiques et de la classe des beauxarts ; Academie royale de Belgique, 6 (1910), pp. 364-388.

Lovejoy, O., The Great Chain of Being, Cambridge, Mass, 1970.

Manero Sorolla, María Pilar, «Ana de Jesús y las biografías del Carmen Descalzo», en Florencio Sevilla y Carlos Alvar (ed.) Actas del XIII Congreso de la Asociación Internacional de Hispanistas, vol. IV, Madrid, AIH/Castalia/Fundación Duques de Soria, 1998, pp. 145-153.

Manero Sorolla, María Pilar, «Cartas de Ana de san Bartolomé a monseñor Pierre de Bérulle», Criticón 51 (1991), pp. 126-130.

Manero Sorolla, María Pilar, «Ana de Jesús, cronista de la fundación del Carmen de granada», en Juan Villegas (coord.), Actas del XI Congreso de la Asociación Internacional de Hispanistas, vol II, Irvine, AIH, 1992, pp. 42-57.

Manrique, Alfonso, La venerable madre Ana de Jesús, discípula y compañera de la S. M. Teresa de Jesús, Bruselas, Lucas de Meerbleck, 1632.

Martínez Hernández, Santiago, El Marqués de Velada y la corte en los reinados de Felipe II y Felipe III. Nobleza cortesana y cultura política en la España del siglo de oro, Valladolid, Junta de Castilla y León, 2004.

Martínez Hernández, Santiago, «Reyna esclarecida, Cynthia clara, hermosa luna: el aprendizaje político y cortesano de la infanta Isabel Clara Eugenia», en C. van Wyhe (dir.), Isabel Clara Eugenia. Soberanía femenina en las cortes de Madrid y Bruselas, Madrid, CEEH, 2009, pp. 20-59.

Martínez Millán, José (dir.), La corte de Felipe II, Madrid, Alianza, 1994.

Martínez Millán, José y Carlos J. Carlos Morales (dirs), Felipe II. La configuración de la Monarquía hispana, Junta de Castilla y León, 1998.

Martínez Millán, José, «El gobierno central de la monarquía: la casa de Felipe II», en Carlos Alberto González Sánchez (ed.), Sevilla, Felipe II y la Monarquía hispana, Sevilla, Ayuntamiento de Sevilla, 1999a, pp. 131-161.

Martínez Millán, José, «La emperatriz María y las pugnas cortesanas en tiempos de Felipe II», en Ernesto Belenguer Cebriá (coord.), Felipe II y el mediterráneo. La monarquía y los reinos, vol. III, Madrid, 1999b, pp. 143-162.

Martínez Millán, José, «La corte de Felipe II: la casa de la reina Ana», en Luis Ribot, (coord.), La monarquía de Felipe II a debate, Madrid, sociedad Estatal para la conmemoración del Felipe II y Carlos V, 2000, pp. 159-184.

Martínez Millán, José y Santiago Fernández Conti (dirs.), La monarquía de Felipe II, La casa del rey, 2 vols., Madrid, Mapfre, 2005. 
Martínez Millán, José y María Antonietta Visceglia (dirs.), La monarquía de Felipe III, 4 vols, Madrid, Mapfre, 2007-2008.

Martínez Millán, José, «La reforma espiritual de Santa Teresa de Jesús y su relación con las facciones cortesanas de la monarquía hispana», Hispania Sacra 67 (2015), pp. 429-466.

Martínez Millán, José y Manuel Rivero Rodríguez (dirs.), La Monarquía de Felipe IV, vol. III/1, 2, 3 y 4, Madrid, Polifemo, 2017.

Meester, B. de (ed.), Correspondance du nonce Giovanni Francesco Guidi di Bagno (1621-1627), vol. I, Bruselas-Roma, 1938.

Michaud, C., «D'une croisade à l'autre, ou de François de la Noue au duc de mercoeur», en J. F. Labourdette, J. P. Poussou y M. C. Vignal, (eds.), La traité de Vervins, Paris, Presses de l'Universitè de Paris-Sorbonne, 2000, pp. 457-472.

Morgain, S. M., Pierre de Bérulle et les carmélites de France : la querelle du gouvernement, 1583-1623, París, Cerf, 1995.

Nieremberg, Juan Eusebio, Obras escogidas (estudio preliminar y edición de Eduardo Zepeda Henriquez), Madrid, Atlas, (BAE), 1957.

Olmedo Ramos, José, «Isabel Clara Eugenia: una infanta de, desde, en, entre las letras del Siglo de Oro», en C. van Wyhe (dir.), Isabel Clara Eugenia. Soberanía femenina en las cortes de Madrid y Bruselas, Madrid, CEEH, 2009.

Optat de Veghel, P., Benoît de Canfield, sa vie, sa doctrine et son influence, Roma, 1949.

Orcibal, José, «La situation en france et le jugement d'Anne de Jesús sur l'ecole abstraite», Le rencontre du carmel thérésien avec les mystiques du nord, Paris, PUF, 1959.

Orcibal, José, Le cardinal de Bérulle : évolution d'une spiritualité, Paris, 1965.

Pasture, A., La restauration religieuse aux pays bas pendant le régime espagnol (1596-1706), Lovaina, 1925.

Pérez-Mínguez, Fidel, D. Juan de Idiáquez. Embajador y consejero de Felipe II, San Sebastián, 1934.

Prodi, Paolo, Il sovrano pontifice. Un corpo e due anime: la monarchia papale nella prima età moderna, Bologna, Il Mulino, 1982.

Prosperi, Adriano, Tribunali della conciencia. inquisitori, confessori, missionari, Torino, 1996.

Puteanus, E., Diva virgo aspricollis: beneficia ejus \& miracvla novissima, Leuven, 1622.

Raeymaekers, D., «Cambio de ceremoniales. Corte y casa en los Países Bajos católicos», en J. Martínez Millán y M. A. Visceglia (dirs.), La monarquía de Felipe III. La casa del rey, vol. 1, Madrid, Mapfre, 2007. 
Raeymaekers, D., «El poder de la proximidad: la cámara de Alberto e Isabel en su corte de Bruselas», en C. Van Wyhe (dir.), Isabel Clara Eugenia. Soberanía femenina en las cortes de Madrid y Bruselas, Madrid, CEEH, 2009, pp. 259-279.

Raeymaekers, D., One Foot in the Palace. The Habsburg Court of Brussels and the Politics of Access in the Reign of Albert and Isabella, 1598-1621, Leuven, University Press, 2013.

Redworth, G., The She-Apostle. The Extraordinary Life and Death of Luisa de Carvajal, Oxford, Oxford University Press, 2008.

Rebreviettes, G., Apotheose chrestienne ov panegyriqve sur les grandes vertus du sereni[ss]imé archiduc Albert, Brussels, 1622.

Rodríguez Villa, Antonio, «Correspondencia de la infanta archiduquesa Doña Isabel Clara Eugenia de Austria con el Duque de Lerma», Biblioteca Virtual Miguel de Cervantes, accesible en línea <http://www.cervantesvirtual.com/nd/ark:/59851/ bmen5906> [consultado el 05/10/2018].

Rodríguez-Salgado, María José, «'Una perfecta princesa’. Casa y vida de la reina Isabel de Valois (1559-1568)», Cuadernos de Historia Moderna 28 (2003), pp. 39-96.

Roggero, A., Genova e gli inizi della reforma teresiana in Italia (1584-1597), Génova, Sagep Editrice, 1984.

Ruiz Martín, Felipe, «Las finanzas españolas durante el reinado de Felipe II», Cuadernos de Historia, Anexos a la revista Hispania 2 (1968), pp. 109-174.

Sánchez, Magdalena S., «Pious and Political Images of a Habsburg Woman at the Court of Philip III (1598-1621)», en Magdalena S. Sánchez, y A. Saint-Saëns (eds.), Spanish women in the golden age. Images and realities, Westport-London, CT: Greenwood Press, 1996, pp. 1599-1611.

Sánchez, Magdalena S., The Empress, the Queen and the Nun. Women and Power at the Court of Philip III of Spain, Baltimore-Londres, Johns Hopkins University Press, 1998.

Sánchez Lora, José Luis, Mujeres, conventos y formas de la religiosidad barroca, Madrid, FUE, 1988.

Santa María (Pulgar), F., Reforma de los descalzos de N. S. del Carmen de la primitiva observancia hecha por Santa Teresa de Jesús en la antiquísima religión fundada por el gran profeta Elías, Madrid, 1644-1655, 2 vols.

Santa Teresa, Silverio, Historia del Carmen descalzo en España, Portugal y América, VIII, Burgos, Monte Carmelo, 1937.

Santos, A., "Orígenes históricos de la sagrada congregación "de propaganda fide"», Revista española de derecho canónico 28 (1972), pp. 509-521.

Schepper, Hugo y Geofrey Parker, «The Formation of Government Policy in the Catholic Netherlands under Archidukes, 1596-1621», English Historical Review 359 (1976). 
Serouet, P., Quintanadueñas. Lettres de Jean de Brétigny (1556-1634), Louvain, Publications Universitaires, 1971.

Serouet, P., Jean de Brétigny (1556-1634). Aux origines du carmel de France, de Belgique et du Congo, Louvain, Bibliotheque de l'Universite, 1974.

Smet, J., Los carmelitas. Historia de la orden del Carmen, II, Madrid, BAC, 1987.

Sommerville, M., Sex and Subjection. Attitudes to Women in Warly-Modern Society, London-New York, Arnold, 1995.

Soto, Andrés de, La contemplación de Christo crucificado y de los dolores que la bienaventura virgen padeció al pie de la cruz, Antwerp, 1601.

Soto, Andrés de, Libro de la vida y excelencias de la gloriosa Santa Ana, madre de la madre de Dios, Brussels, 1607.

Soto, Andrés de, Breve declaración de la cofradía de los siete dolores, Brussels, 1615.

Soto, Andrés de Declaracion de los biennes y excellencias de la paz, Amberes 1621

Teresa de Jesús, Obras completas, III, edición de Efrén de la Madre de Dios y Otger Steggink, Madrid, BAC, 1959.

Thomas, W., «The "Spanish Faction" at the Court of the Archdukes Albert and Isabella», en R. Vermeir, D. Raeymarkers y J. E. Hortal Muñoz (eds.), A Constellation of Courts. The Courts and Households of Habsburgo Europe, 15551665, Leuven, University Press, 2014, pp. 167-221.

Thomas, Werner y Luc Duerloo, Albert and Isabella, 1598-1621, Bruselas, 1999.

Tormo, Elías, En las descalzas reales de Madrid. Estudios históricos, iconográficos y artísticos, Madrid, 1917.

Torres, C., Ana de Jesús. Cartas (1590-1621), Salamanca, Ediciones Universidad, 1996.

Urkiza, Julen, «Ana de San Bartolomé e Isabel Clara Eugenia. Dos mujeres dirigentes de la vida social y religiosa en Flandes (entre treguas y guerras buscando la paz)», Monte Carmelo 114 (2006), pp. 319-380.

Valladares, Rafael, «Decid adiós a flandes: la monarquía hispánica y el problema de los Países Bajos», en Thomas Werner y Luc Duerloo, Albert and Isabella, 15981621, Bruselas, 1999, pp. 47-54.

Vermeir, René, «La infanta Isabel Clara Eugenia y la corte pontificia, 1621-1633», en C. van Wyhe (coord.), Isabel Clara Eugenia. Soberanía femenina en las cortes de Madrid y Bruselas, Madrid, CEEH, 2004, pp. 341-342.

Vernulæus, N., Oratio funebris in obitum Alberti archiducis austrice, ducis burgundice, principis belgarum, Leuven, 1622.

Villermont, M. de, L'infante Isabelle, gouvernante des Pays-Bas, II, Paris, 1912.

Weber, A., «María de San José (Salazar): Saint Teresa's "Difficult” Daugther », en C. Wilson (ed.), The Heirs of St. Teresa of Ávila: Defenders and Disseminators of the Founding Mother's Legacy, Washington D. C., Institute of Carmelite Studies, 2006, pp. 1-20. 
Wyhe, Cordula van, Umble Wife, Charitable Mother and the Chaste Widow: Representig the Virues of the Infanta Isabella Clara Eugenia (1599-1633), University of London, (tesis doctoral), 2001.

Wyhe, Cordula van, «Court and Convent. The Infanta Isabella and her Franciscan Confesor Andrés de Soto», Seventeenth Century Jornual 35/2 (2004), pp. 411-445.

Wyhe, Cordula van, «Between Chastity and Passion. The Impact of the French Exiles on the Cult of Courtly Love at the Brussels Court in the 1639's», en Johann A. Steiger y Ralph G. Bogner (eds.), Passion. Affekt un Leidenschaft in the frühen Neuzeit, Wolfenbütteler Arbeiten zur Barockforschung, vol. II, Wiesbaden, Harrassowitz, 2005, pp. 951-980.

Wyhe, Cordula van, «Piety and Politics in the Royal Convent of Dicalced Carmelite Nuns in Brussels, 1607-1646», Revue d'histoire ecclesiastique, 100 (2005), pp. 457-487. 